\title{
European Antitrust Policy 1957-2004: An Analysis of Commission Decisions
}

\author{
Martin Carree • Andrea Günster • \\ Maarten Pieter Schinkel
}

(C) The Author(s) 2010. This article is published with open access at Springerlink.com

\begin{abstract}
This paper provides a survey of European antitrust law enforcement since its foundation in the Treaty of Rome of 1957 up to and including 2004. We present a complete overview and statistical analysis of all 538 formal Commission decisions under Articles 81, 82, and 86 of the European Community Treaty. We report a range of summary statistics concerning report route, investigation duration, length of the decision, decision type, imposed fines, number of parties, sector classification, nationality, and Commissioner and Director General responsible. The statistics are linked to changes in legislation and administrative implementation, thereby providing an historical overview that summarizes the Commission's work in the area of antitrust. One or more appeals were filed with respect to 161 of the 538 decisions. We estimate
\end{abstract}

We thank Joris Bijvoet, Norman Bremer, Corinne Dussart-Lefret, Francesco Russo, and Ida Wendt for their assistance in systematically collecting the data that underlie our analyses. Kati Cseres, Vivek Ghosal, John Kwoka, Bruce Lyons, Francesco Russo, Floris Vogelaar, Wouter Wils, the editor, and two referees provided useful comments. We also are indebted to participants at EARIE 2004 (Berlin), EARIE 2006 (Amsterdam), IIOC 2007 (Savannah), the 2007 PhD Workshop at the Center for Competition Policy (Norwich), and the 2008 ACLE conference "EC Competition Enforcement Data" (Amsterdam). Financial support from METEOR and ACLE is gratefully acknowledged. Opinions and errors remain ours.

\section{Carree $(\bowtie)$}

Department of Organization and Strategy, Maastricht University, P.O. Box 616, 6200 MD, Maastricht, The Netherlands

e-mail: m.carree@maastrichtuniversity.nl

\section{A. Günster}

ETH Zurich, Professorship for Intellectual Property, Raemistrasse 101, 8092 Zurich, Switzerland e-mail: andrea.guenster@ip.gess.ethz.ch

\section{P. Schinkel}

Department of Economics and ACLE, University of Amsterdam, Roetersstraat 11, 1018 WB,

Amsterdam, The Netherlands

e-mail: m.p.schinkel@uva.nl 
the determinants of the size of the imposed fine and probability of appeal when an infringement has been found.

Keywords Antitrust $\cdot$ Appeal $\cdot$ Competition policy $\cdot$ European Commission

JEL Classification $\quad \mathrm{L} 40 \cdot \mathrm{K} 21$

\section{Introduction}

European competition policy is a visible and much debated part of the activities of the European Commission. This paper surveys the implementation of antitrust law in the European Community (EC) from its establishment in 1957 up to its modernization in 2004.

We characterize more than forty years of European competition policy enforcement in summary statistics on 538 formal antitrust decisions in total, providing an analysis of all formal Commission decisions in antitrust cases pursuant to Articles 81, 82, 86, and Council Regulation 17. Information was collected for each of these European Commission antitrust cases on such variables as length of decision, duration of the investigation, nationality of firms, nature of the alleged offence, level of fines imposed, the Commissioner who signed the decision, and whether there was an appeal of the case. The summary statistics are interpreted and, where possible, linked to changes in legislation and administrative implementation. In addition, we offer a statistical analysis of the fine per case and per individual firm and of the probability that a finding of an infringement is appealed to the Court of First Instance (CFI)/European Court of Justice (ECJ).

The survey is based upon an extensive data set in which we consistently collected publicly available information on the decisions of the Directorate General for Competition (DG Comp) contained in their publication in the Official Journal of the European Communities. Our analyses neither include European merger and State aid decisions, which are several thousands each, nor decisions under the earlier European Coal and Steel Community Treaty. ${ }^{1}$

In the following sections, we present statistics from the first formal decision, published in 1964, up to the last in 2004. We chose 2004 as the last year of investigation for various reasons. First and foremost, this allowed us to get complete information on each of the cases. Several later decisions are still unpublished, as confidentiality issues are being cleared. In addition, on 1 May 2004 Council Regulation 1/2003 came into force to replace Council Regulation 17 of 1962. This radically changed enforcement procedures. Finally, in November 2004 Competition Commissioner Mario Monti's period in office ended, when he was succeeded by Commissioner Neelie Kroes.

Before presenting our statistical findings, we need to enter an important caveat with respect to the use of enforcement data and what can be learned from them. We analyse formal decisions produced by the European Commission. Hence, we do not present

\footnotetext{
1 On merger control in the European Union, see Davies and Lyons (2007). On the economics of European State aid, see Friederiszick et al. (2006).
} 
information on cases that the Commission has investigated but were dropped due to lack of evidence uncovered. Formal decisions may present a small and selective sample of the entire population of underlying European competition law infringements. The size of the latter population is hard to estimate. Therefore, we are also not able to investigate to what extent competition enforcement has deterred illegal acts. For these reasons, the reader should consider our analysis as a broad historical overview summarizing the Commission's work and much less as an appraisal or critique.

The remainder of this paper is organized as follows: The following section offers a brief review of the related literature. Section 3 reviews the European competition rules on antitrust. In Sect. 4, the Commission decisions are summarized over time and classified according to origin and type. In Sect. 5, the Commission's decisions are considered by main categories of economic conduct. Section 6 analyses decisions by sector. In Sect. 7, several statistics are presented on European antitrust enforcement, such as length and depth of investigation and measures of output per Commissioner. Section 8 analyses trends in remedies and sanctions, including a regression analysis that attempts to explain the size of fines per case or per firm. Section 9 presents a probability analysis of appeals proceedings, and Sect. 10 concludes. A description of the data sources used to compile the set of European Commission decisions on antitrust on which we draw is given as an "Appendix".

\section{A Brief Literature Review}

To our knowledge, we are the first to present a complete statistical summary of European antitrust cases. Federal antitrust enforcement in the United States, which has a history that is more than twice as long (the Sherman Act was enacted in 1890), has been a rich source of empirical analysis. Several studies consider the actions of the US Department of Justice's Antitrust Division and the Federal Trade Commission since the seminal survey by Posner (1970). Examples include Gallo et al. (1985), Salop and White (1986), Gallo et al. (1986), Corwin (1992), Gallo et al. (1994), Gallo et al. (2000), Lin et al. (2000), Kovacic and Shapiro (2000), Ghosal and Gallo (2001), Posner (2001), Baker (2003) and Ghosal and Stennek (2007).

A developing literature is concerned with the empirics of European competition law enforcement. It focuses mostly on European merger control. See for example Nillsen et al. (1997), Duso et al. (2007), Lyons (2004), Bergman et al. (2005), Duso et al. (2006) and Davies and Lyons (2007). Russo et al. (2010) provide a catalogue of all landmark antitrust and merger cases. Schinkel (2007) and Veljanovski (2007) survey European cartel enforcement. Stephan (2005) critically considers the results of the 1996 leniency notice. Geradin and Henry (2005) and Bos and Schinkel (2006) analyze the Commission's fining guidelines for breach of Articles 81 and 82. Wils (2002, 2005) offers contributions on European antitrust enforcement from a law and economics perspective. Gual and Mas (2005) explore a unique data set on the genesis of European Commission decisions to estimate the probability of adverse findings in Article 81 and 82 investigations in the period from 1999 to 2004, given relevant industry-level variables. Harding and Gibbs (2005) discuss the success rate of cartel appeal pro- 
ceedings before the European appellate courts during the period from 1995 to 2004. Neven (2006) estimates the size of the effect of European competition policy.

There also are a few empirical studies of antitrust enforcement in individual European Union Member States. Shaw and Simpson (1986) establish a significant decrease in market shares by leading companies after a UK Monopolies and Mergers Commission (now the Competition Commission) investigation. Davies et al. (1999) determine the probability of an adverse finding against firms that were investigated between 1973 and 1995. Lauk (2002) similarly investigates decisions of the German Bundeskartellamt on abusive practices and cartels taken between 1985 and 2000. There furthermore are a number of scholarly legal publications that collect European Commission decisions or Court of Appeal sentences on competition and discuss selected landmark decisions in detail, including Jones and van der Woude (2006), Faull and Nikpay (2007), Ritter and Braun (2005), and Vogelaar (2007).

\section{The European Competition Rules on Antitrust}

The foundation of European competition policy was laid in the Treaty of Rome in 1957, which succeeded the 1951 Treaty of Paris that had established the European Coal and Steel Community (ECSC). Article 3(1)(g) of the Treaty of Rome identifies as one of the general objectives of the European Community the achievement of "a system ensuring that competition in the internal market is not distorted". The European Commissioner for Competition enforces the rules established in European competition law, assisted by the Directorate-General for Competition (hereafter DG Comp) and in close cooperation with the national competition authorities of the Member States.

DG Comp prepares decisions in three broad areas: antitrust, mergers, and State aid. Each year, several hundred cases are investigated. Over the period 2000-2004, the average number of new antitrust cases that were investigated per year was 264. In addition, there was a yearly average of 284 new merger cases and 1,075 new State aid cases. $^{2}$ Recent examples of high-profile cases include the 2009 fine of $€ 1,060$ million levied on Intel for abuse of dominance, the 2007 fine of $€ 992$ million for five elevator producers for colluding to fix prices, and the Commission's decision to block the merger between General Electric and Honeywell-which had previously been approved by the US competition authorities.

There were several changes made to the regulatory framework over the history of European competition policy. The Treaty of Rome, Article 211, empowers the Commission to apply its regulations, directives, and decisions adopted under the Treaty's rules, to formulate recommendations, and to deliver opinions. The European Competition rules are embodied in the Treaty Articles, Council and Commission Regulations, and Commission notices and guidelines. The last two serve as guidance and are not legally binding.

Enforcement powers related to the competition rules were made effective in 1962 by Council Regulation 17, which was initially proposed by Commissioner Hans von

\footnotetext{
${ }^{2}$ XXXV Annual Report on Competition, 2005.
} 
der Groeben. This regulation gave the Commission the role of central enforcement authority with procedural autonomy and institutional neutrality. In essence, Regulation 17 granted the Commission the possibility to take action in the form of opening investigations, taking decisions and imposing remedies and sanctions. The first European Commission decision on competition, in Grosfillex \& Fillistorf, is dated 11 March 1964. Since our analysis spans the period until 2004, we refer entirely to decisions that fell under the first Council regulation. This regulation was replaced by Regulation $1 / 2003$, which has been in force since May 2004, initiating the modernization process.

Articles 81 and 82 of the Treaty of Rome are intended to protect the competitive processes in the Community's common market from anticompetitive conduct, for the benefit of consumer welfare. ${ }^{3}$ The Treaty Articles describe the illegal anticompetitive practices whereas Regulation 17 provided the executive mechanism to act against them. Article 81(1) of the EC Treaty establishes the prohibition of agreements and concerted practices among undertakings that affect trade between Member States as well as restricting competition within the common market.

It is possible to identify four main types of economic agreements or concerted practices to which Article 81 applies: horizontal conduct, vertical restraint, licensing, and joint ventures. ${ }^{4}$ Note that Article 81 covers the full breadth of agreements from hardcore cartels to legitimate agreements like research joint ventures.

Based on Regulation 17, Commission investigations could translate into one of three decisions: negative clearance, exemption, or infringement: ${ }^{5}$

- A negative clearance follows when Article 81(1) does not apply to the case under consideration on the basis of the information available at the time: The agreement or practice is in accordance with existing Community law.

- Exemptions are granted when Article 81(1) applies to a notified case, but circumstances specified in Article 81(3) also apply. Exemptions are granted only temporarily. Article 81(3) in particular facilitates the creation of joint ventures or shared patent agreements with the intent to foster innovation. Industries were twice in a structural crisis and therefore under Article 81(3) were temporarily allowed to form cartels: during the oil shock in the early 1980s, and during the recession of the early 1990 s. ${ }^{6}$ In addition, early regulations exempted certain sectors from application of the EU competition laws: Council Regulation 141 of 1962, for example, exempted the transport sector.

\footnotetext{
3 The original Treaty text has been amended several times over the history of the EC, the latest in the Treaty of Nice in 2001. The current numeration of the articles, also used throughout this paper, was adopted by the Treaty of Amsterdam in 1997 and entered into force in 1999. Previously, Articles 81 and 82 were numbered 85 and 86 in the Treaty of Rome.

4 Since 1998 full function joint ventures are decided under the Merger Regulation; see Council Regulation 1310/97/EC of 30 June 1997 on the control of concentrations between undertakings.

5 There is a (seldomly used) possibility for an interim measure, which might be considered as a fourth category.

6 XXIII Report on Competition Policy, 1993, p. 49. The four cases were International Energy Agency Commission decision 83/671/EEC [1983] OJ L 376/30, Case IV/30.525; Synthetic Fibres Commission decision 84/380/EEC [1984] OJ L 207/17, Case IV/30.810; International Energy Agency Commission decision 94/153/EEC [1994] OJ L 68/35, Case IV/30.525; Stichting Baksteen Commission decision 94/296/EEC [1994] OJ L 131/15, Case IV/34.456.
} 
- The Commission issues an infringement decision whenever Article 81(1) applies but none of the conditions mentioned in Article 81(3).

Article 82 prohibits taking anticompetitive advantage of a dominant position. All investigations of an abuse of dominance that are concluded with a formal decision under Article 82 were infringements, with the exception of one case involving minority shareholder agreements before the introduction of the Merger Regulation in $1989 .{ }^{7}$ Unlike under Article 81 there is no possibility for exemptions or negative clearances. Until the Merger Regulation came into force in 1990, five merger cases were decided under Article 82. Article 82 abuses include discriminatory sales conditions and monopolization strategies through tying and bundling and predatory pricing. Article 82, in conjunction with Article 86, also applies to situations of dominance that are maintained or fostered by Member State regulation. Article 86 can, for example, be used in relation to the process of state monopoly liberalization.

The Commission uses block exemption regulations in relation to certain forms of economic conduct, as well as to small and medium size enterprises, partly to alleviate its work load by lifting the notification requirement. ${ }^{8}$ Two notices of December 1962 placed exclusive agency contracts made with commercial agents and patent licensing agreements outside the immediate scope of European competition law. ${ }^{9}$ In the first half of the 1980s, multiple block exemption regulations were issued: for example, for specialization and R\&D joint ventures and exclusive distribution and purchasing, as well as for patent and know-how licensing. ${ }^{10}$ Block exemptions often follow a short string of pilot decisions on a particular topic.

Increasingly, the Commission used "comfort letters" to deal with notifications. A comfort letter is not a formal decision, but instead is a notice to companies that, while there may be further investigations with ramifications, these would be applied mildly. ${ }^{11}$ In addition, the Commission adopted the 'de minimis doctrine' for cases involving agreements of minor importance. ${ }^{12}$ This was in part in response to a need for appreciability standards created by a number of court decisions. ${ }^{13}$ All of this helped

\footnotetext{
7 There was a negative clearance for Metaleurop SA Commission decision 90/363/EEC [1990] OJ L 179/41, Case IV/32.846.

8 VII Report on Competition, 1977, p. 28.

9 Commission Notice of 24 December 1962 on Exclusive Agency Contracts made with Commercial Agents; Commission Notice of 24 December 1962 concerning Patent Licensing Agreements. These notices later led to Council Regulation 19/65 on patent licensing and Commission Regulation 67/67 on exclusive distribution cases.

10 See Commission Reg. 2349/84/EEC of 23 July 1984 on the application of Article 85(3) of the Treaty to certain categories of patent licensing agreements; Commission Reg. 417/85/EEC of 19 December 1984 on the application of Article 85(3) of the Treaty to categories of specialization agreements; Commission Reg. 418/85/EEC of 19 December 1984 on the application of Article 85(3) of the Treaty to categories of research and development agreements.

11 The existence of comfort letters is only required to be mentioned in the Official Journal when a comfort letter is sent in response to a notification or a complaint. The lack of full publication in public sources prevented us from including comfort letters in our analyses.

12 These are Commission Notices on agreements of minor importance that do not appreciably restrict competition under Article 81(1) of the Treaty establishing the European Community (de minimis) (2001/C 368/07).

13 In particular in Case 5/69 Völk V. Varvaecke (1969) ECR 295.
} 
to accelerate the decision-making process and clear the Commission's large backlog of more than four thousand notifications, which had accumulated in the 1960s and the 1970s. The backlog was greatly reduced even while the number of Member States was increasing. ${ }^{14}$

In 1989, the Court of First Instance was established to deal as the first appellate court for appeals of Articles 81 and 82 Commission decisions. Its creation allowed the European Court of Justice to concentrate on appeals proceedings that involve Member States, and second instance appeals exclusively on points of law. The CFI constituted greater control over the Commission's growing use of its powers in the area of competition. In the same year, the introduction of the Merger Regulation implied a reallocation of institutional resources to the newly established Merger task force that deals with required notifications and strict deadlines for Commission decisions. ${ }^{15}$ Beforehand, the only five merger cases decided by the Commission were dealt with under Article 82. Since the introduction of the Merger Regulation, merger enforcement is a separate category of competition policy enforcement and no longer falls under "antitrust" enforcement in the Community.

DG Comp—named DG IV prior to 1999-also expanded over time, adding sectorspecific units. In 1998, the first anti-cartel unit was formed, initially with some twenty specialized officials. This unit deals with cartel formation throughout all sectors of the economy. The set of enforcement instruments of the DG Comp had already been extended in 1996 with the introduction of the leniency program. It aimed to encourage participants of cartels to inform the authorities of their involvement in (until then) unknown collusive arrangements, in exchange for a full or partial reduction in fines. ${ }^{16}$ After revisions in 2002 and again in 2006, a substantial number of leniency applications have been made. With the revised leniency program, the Commission created a second anti-cartel unit.

DG Comp is not the only antitrust authority in Europe. Germany, the UK, and France have competition authorities that have enforced national as well as European competition law for decades. Nowadays all Member States have national competition authorities (NCAs) that deal with cases that have a (mainly) national impact, while the Commission covers cases in which multiple Member States are affected, as well as cases that are regarded as prominent. Cooperation between the Commission and the NCAs of the Member States has grown stronger over the years.

Many Commission decisions on both mergers and antitrust cases have been successfully appealed to the CFI/ECJ, increasingly on economic grounds. The Commission has sought to strengthen its in-house economic expertise with the creation of the position of Chief Competition Economist and its support team of economists in 2003. In addition, the Economic Advisory Group on Competition Policy, a group of

\footnotetext{
14 XIX Report on Competition, 1990, p. 44.

15 The current Merger Regulation is from 2004. See Council Reg. 139/04/EC of 20 January 2004 on the control of concentrations between undertakings.

16 Commission Notice on immunity from fines and reduction of fines in cartel cases (Leniency Notice) of 18 July 1996; Commission Notice on immunity from fines and reduction of fines in cartel cases of 19 February 2002; Commission Notice on Immunity from fines and reduction of fines in cartel cases (New Leniency Notice) of 8 December 2006.
} 


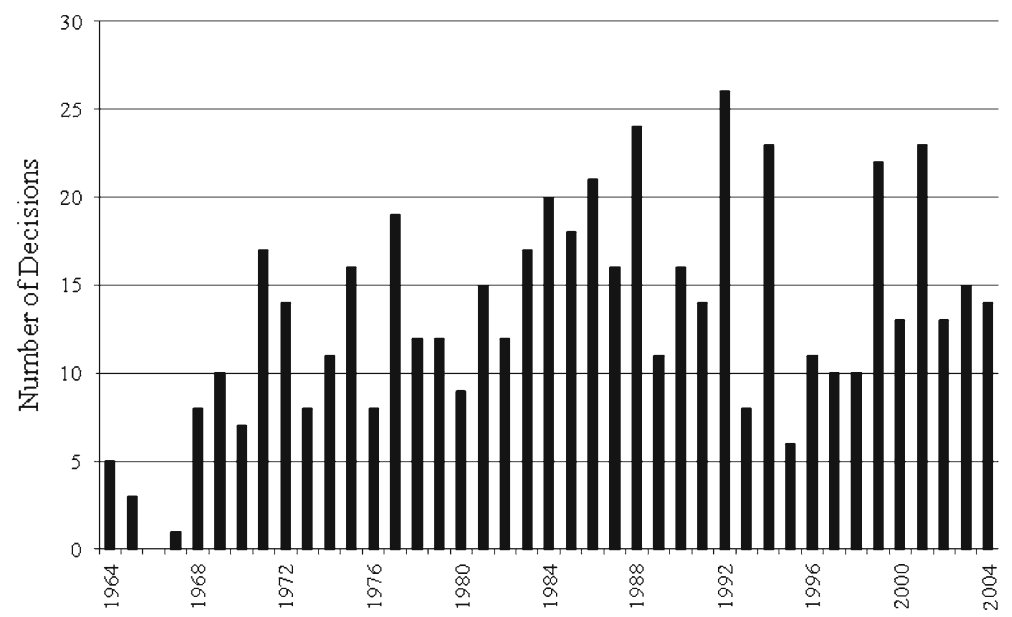

Fig. 1 Total number of Commission decisions on antitrust per year

leading academic economic advisors, was formed. These developments, together with increased international cooperation with antitrust agencies worldwide through transAtlantic agreements and the International Competition Network (ICN), have advanced an economic effects-based approach to the Commission's decisions on antitrust. ${ }^{17}$

\section{Commission Decisions Over Time by Type and Origin}

Figure 1 shows the distribution of the 538 separate formal antitrust decisions in the period 1964-2004. ${ }^{18}$ During the first few years after the approval of Regulation 17 of 1962 the Commission took and published only few decisions. Thereafter, their number rose steadily over the years, although the numbers tend to differ substantially from one year to another. A peak in the number of cases was reached in 1992, and was then followed by a substantial drop. ${ }^{19}$

The early upward trend reflects DG Comp's growing legitimacy and jurisdiction. The upward trend continued until 1988, but this was followed by a general decrease in the average number of formal decisions per year. This may be explained by the measures that were introduced to reduce the Commission's workload, such as the block exemption regulation system and a stronger reliance on comfort letters instead of official decisions in this period. In addition, around 1989 the DG Comp was burdened with enforcement of the then new merger control regulation. The merger task force

\footnotetext{
17 See Roeller and Stehmann (2006).

18 The number of cases that the DG Comp effectively dealt with is substantially higher than the number of decisions that are displayed in the figures, which include only the formal decisions.

19 We checked for influences of business cycles and size of the European Community using a regression model with the number of cases per year as the dependent variable. The independent variables included a trend, GDP growth (retrieved from the World Development indicators), and the number of Member States. The only significant coefficient was that of the trend.
} 


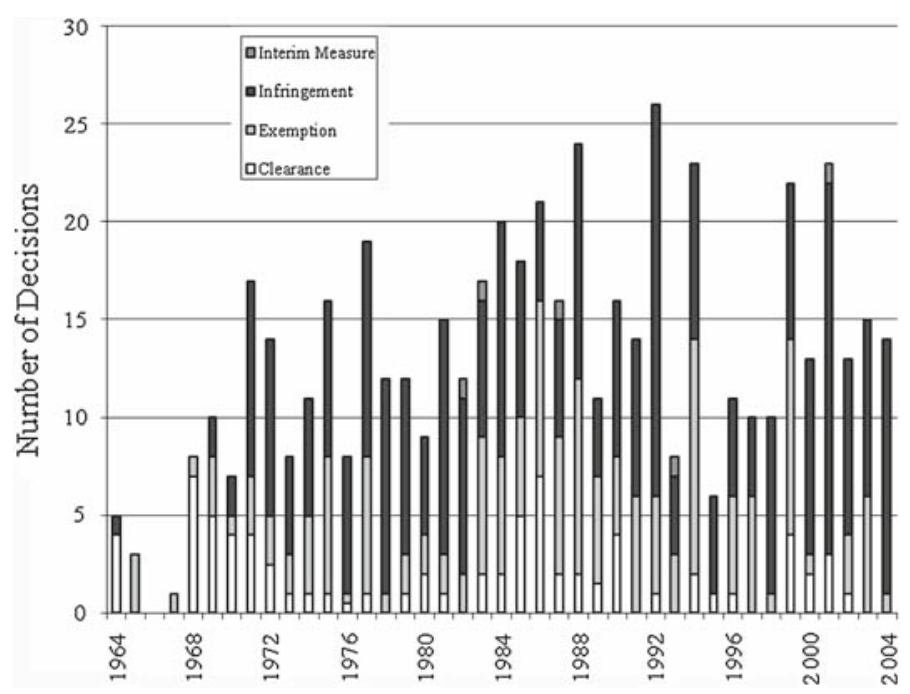

Fig. 2 Types of formal Commission decisions per year

was initially recruited from DG Comp staff, leaving less capacity to address antitrust cases. Note again that the number of cases (or even infringements) tells little about the size and shape of the pool of European antitrust violations.

An interesting pattern emerges when we organize all formal decisions by the month of the year in which each decision was taken. We find that over half of the cases are decided in just two months: 17 per cent in July, and 37 per cent in December. Hence, there are peaks before the summer break in August and before Christmas. There is no such concentrated pattern in the opening months of investigations. There are also clear concentrated periods of high productivity at the end of the terms of a Competition Commissioner. In 1988, when Commissioner Sutherland ended his term, he took the majority of decisions in his last month in office (December). The ending of Commissioner Brittan's term explains the peak in 1992. Commissioner Van Miert took over in January 1993, and the following peak is in 1999, the end of his term.

Figure 2 displays the same total numbers as the previous graph, categorized by the type of formal decision: interim measure, infringement, exemption, or negative clearance. In the early stages of EC competition law enforcement, the Commission concluded its investigations mainly by issuing negative clearances and exemptions. Two years after Regulation 17 was adopted, in March 1964, the first antitrust decision on record, Grossfillex and Fillistorf, was a negative clearance under Article 81(1) for a vertical agreement. ${ }^{20}$ Another four decisions followed that year. With only another four decisions in total in the years 1965-1967, 1968 saw an increase to eight in that year alone. In the year 1971, with 17 decisions, enforcement for the first time overshot what would become the average of 13 decisions per year in the Commission's effective policy period between 1964 and 2004.

${ }^{20}$ Grosfillex \& Fillistorf Commission decision 64/233/EEC [1964] OJ L 64/915, Case IV/61. 
The first finding of an infringement was in September 1964, in the Commission's fourth decision, Grundig-Consten. ${ }^{21}$ The agreement between the two firms was concluded to be a breach of Article 81(1), and ordered to be discontinued. This first adverse finding was appealed to the ECJ. The ECJ largely upheld the decision in its first appeal ruling in European antitrust law, in June 1966. Only in July 1969 did the Commission find infringements again, in the Quinine cartel case, with a total fine of $€ 500,000$, and in the Dyestuffs cartel case, with a total fine of $€ 490,000$. $^{22}$ In the Quinine cartel a breach of Article 81(1) was found, in the form of horizontal market sharing, quota arrangements, and price fixing. The German Bundeskartelamt had earlier found evidence against the firms involved in the arrangement. The decision was appealed with limited success in three distinct ECJ cases by ACF Chemiefarma, Buchler \& Company, and Boehringer Mannheim. The ECJ largely upheld the Commission's decision. The Dyestuffs international cartel case, an industry with a long history of monopolization, is seminal for its international dimension and has served in subsequent Annual Reports as a benchmark. ${ }^{23}$

Figure 2 shows that from the early 1970s onwards, the number of infringements found increased relative to exemptions and negative clearances. For further analysis, we have divided the total enforcement period since 1964 into three periods of equal length. The first enforcement period runs from 1964 to 1977. This is the starting phase of competition law enforcement when administrative processes had to be developed and a sizeable effort went into the design of block exemption regulations. The second period is from 1978 to 1990 . This was a period of increased unification in Europe striving for a single market. While it existed since the Treaty of Rome, in 1979 the European Parliament was for the first time directly elected by the people of the European Community. This period closes just when the CFI and the Merger Regulation had become effective. An accumulated back-log of cases was cleared under Commissioner Leon Brittan at the very beginning of the 1990s. ${ }^{24}$ The third enforcement period, from 1991 to 2004, is characterized by a number of innovations in enforcement that were aimed in particular at combating cartels, including the introduction of leniency programs and the establishment of designated anti-cartel units. ${ }^{25}$

Annual formal decisions totalled 127, 203, and 208, respectively, in the three consecutive enforcement periods. The share of negative clearances decreased gradually over the three enforcement periods from 24 to 15 to 7 per cent of formal decisions. The percentage of exemptions remained constant at around 30 per cent. The largest category was that of infringements. Already in the period from 1964 to 1977, infringe-

\footnotetext{
21 Grundig-Consten Commission decision 64/566/EEC [1964] OJ L 64/2545, Case IV/3344.

22 Quinine Commission decision 69/240/EEC [1969] OJ L 192/5, Case IV/26.623 and Dyestuffs Commission decision 69/243/EEC [1969] OJ L 195/11, Case IV/26267. For convenience, the fines are expressed as Euros instead of ECU.

23 I Report on Competition (1971), p. 28; VI Report on Competition (1977), p. 32; XI Report on Competition (1981), p. 38.

24 The number of cases pending dropped from 3239 in 1989 to 1231 only three years later. Many of these cases dealt with notified agreements that were no longer in force.

25 We tested for structural breakpoints in the number of cases for the two years 1977 and 1990 using a Chow breakpoint test. The test statistic showed significance at the $10 \%$ significance level.
} 
ments accounted for 48 per cent, rising to 64 per cent during the last period. The rise in infringement decisions since 1998 is largely due to the Commission creating the first anti-cartel unit and starting to receive leniency applications under the leniency program that was introduced in 1996.

Under Regulation 17, there are three types of report routes with which cases enter DG Comp: First, Regulation 17 introduced a notification requirement for firms, making it compulsory to inform the Commission about existing or planned agreements and concerted practices. Immunity against fines was then in principle guaranteed, although it could be lifted by the Commission (Article 15 of Regulation 17). Block exemption regulations concerning conduct, sector, and the de minimis doctrine made notifications obsolete whenever they applied. Since the introduction of Regulation 1/2003, the notification system has been abolished. Second, individuals or firms could file a complaint against a certain conduct. Finally, Regulation 17 also enabled the Commission to investigate on its own. For example, it granted the Commission the power to send a statement of objections, require information, and enter the premises of firms with the aim of finding evidence. In 1996, the leniency notice introduced a fourth report route.

Figure 3 displays the report route of the cases. It reveals that leniency applications had an important impact for 2001 and onwards. Two years after the introduction of the leniency program, British Sugar was the first decision in which leniency played a role. ${ }^{26}$ Advocates of the availability of leniency often take the large number of leniency cases as a measure of the program's success. In addition, the information provided by the parties in their applications has accelerated case processing. One of the European cartel cases that was most swiftly dealt with is Fine Art Auction Houses, the first cartel decision made under the revised 2002 leniency notice after only a half-year of investigation in 2002. 27

Another clear trend in Fig. 3 is the role of notifications in initiating formal decisions, which has decreased significantly since the 1990s due to the block exemption regulations, increased use of comfort letters, and the rise of leniency applications. Increasingly, decisions are classified as originating from the Commission's own initiative. Thus the abolishment of the notification system as of May 2004 came at a time when the share of notifications in formal decisions was already falling. Notifications as the origin of a case decreased from seven out of ten cases between 1964 and 1977 to less than four out of ten in the period 1991-2004.

Formal decisions on cases brought to the Commission by complaints have been increasing over the years from 9 (1964-1977) to 19 per cent (1978-1990) to 24 per cent (1991-2004). Parties with a legitimate interest may lodge a complaint. Nonetheless, the Commission has discretionary power in handling complaints. It can reject a complaint, which it must then motivate in a written decision to the complainant, which is subject to appeal. Although they carry the risk of selection bias whenever a related individual strategically abuses filing complaints to delay the introduction of an agreement or practice, complaints are an essential source of information for the

\footnotetext{
${ }^{26}$ British Sugar Commission decision 1999/210/EC [1999] OJ L 76/1, Cases IV/33.708, 33.709, 33.710, 33.711

27 Fine Art Auction Houses Commission decision 2005/590/EC [2005] OJ L 200/92, Case COMP/E$2 / 37.784$.
} 


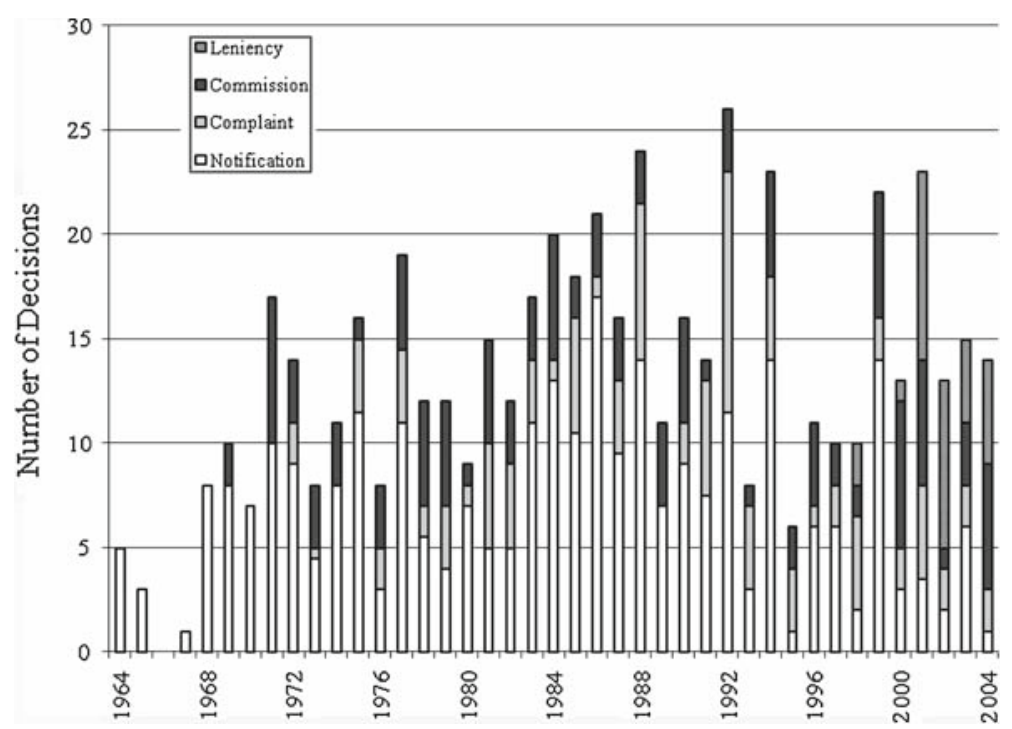

Fig. 3 Report route of Commission decisions on antitrust

Commission. The data suggest that initially potential complainants needed some time to become aware of the possibility to complain about suspected anti-competitive behavior of rivals, suppliers, or distributors. However, a substantial part of the decisions that are registered as the Commission's own initiative may in fact have been complaints by parties that preferred to remain anonymous. This effect may have been stronger in early periods than it is today.

Table 1 displays the Commission's official decisions and their report routes for the entire enforcement history. The bottom part of the table shows that a hypothesis of independence between report route (horizontal) and decision type (vertical) is rejected. Hence, knowing the report route of a case helps predict its decision type. We systematically incorporate such Chi-square tests of independence in our subsequent tables. Almost one in four notifications resulted in an infringement, but a negative clearance was slightly more likely. The majority of notifications was exempted. The other categories are almost exclusively connected to infringements in the table.

This pattern should not be interpreted as a causal relation, as if complaints or investigations initiated by the Commission lead in a large majority of cases to an infringement decision. Only those investigations that are initiated by complaints or by the Commission's own efforts and that result in enough evidence to establish an infringement are formally decided upon by the Commission. An example of one of the few cases in which a Commission's initiative did not lead to an infringement is Bayer/Gist-Brocades. ${ }^{28}$ After the Commission opened an investigation in December 1974 , a prompt notification by the parties led (roughly one year later) to an exemption for cooperation in production, sales, and distribution for eight years with conditions.

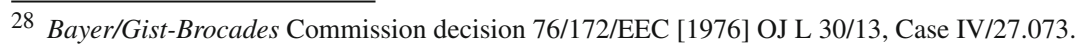


Table 1 Formal decisions by report route

\begin{tabular}{lccccc}
\hline & Negative clearance & Exemption & Infringement & Interim measure & Total \\
\hline Notification & 73.25 & 151.75 & 62 & 0 & 287 \\
Complaint & 1.25 & 1.75 & 92.5 & 4 & 99.5 \\
Commission & 1 & 3 & 117.5 & 1 & 122.5 \\
Leniency & 0 & 0 & 29 & 0 & 29 \\
Total & 75.5 & 156.5 & 301 & 5 & 538 \\
\hline
\end{tabular}

The hypothesis of independence between report route and decision type is rejected at a one per cent significance level (Chi-square statistic is 320.679 with 9 d.f.)

Cases may have more than one report route and type of formal decision, resulting in the fractions in the table. In nine decisions simultaneous exemptions and negative clearances were granted under Article 81

\section{Commission Decisions by Type of Economic Conduct}

We distinguish six main categories of economically motivated types of findings in the Commission's antitrust decisions. These are Article 81 decisions on horizontal constraints, licensing, vertical restraints, and joint ventures; Article 82 cases on abuse of dominance; and Article 86 cases addressed to Member States. Procedural decisions constitute a separate category. ${ }^{29}$

Table 2 displays the distribution of economic findings by decision types. Note that a number of cases are in multiple categories. An example is the Warner-Lambert/ Gilette and Bic/Gilette case. ${ }^{30}$ It concerned a notified shareholding agreement, about which complaints had been made as well. Since the decision had horizontal as well as dominance aspects, we include it as 0.5 notification, 0.5 complaint, 0.5 horizontal, and 0.5 abuse of dominance. Article 82 and procedural decisions are almost always infringements. Most joint ventures that make it to the stage of a formal decision are exempted; the rest are likely deterred or modified. Note that these numbers should not be interpreted strictly as the probabilities of adverse findings in investigations, since it is likely that many Commission investigations are never concluded with a formal decision, but instead are not pursued or are otherwise informally resolved.

The majority of formal decisions on horizontal cases and cases on vertical restraints are infringement findings. Licensing cases display an equal distribution across negative clearances, exemptions, and infringements. The Chi-square test on independence between economic conduct and the decision type reveals that the probability of finding a specific decision is dependent upon the conduct that the firm exercises.

Figure 4 presents the seven categories of economic findings per sub-period. Horizontal constraints consistently are the largest category. In the period 1964-1977, they constitute almost half of all cases, including landmark decisions like Quinine, the

\footnotetext{
29 Procedural decisions are Commission decisions that are adopted pursuant to Regulation 17 of 1962, Art. 11, which concerns the Commission's right to ask information, and Art. 15-16, the Commission's right to impose fines. These articles correspond-notwithstanding differences-to current Articles 18, 23, and 24 of Regulation 1/2003.

30 Warner-Lambert/Gilette and Bic/Gilette and others Commission decision 93/252/EEC [1993] OJ L 116/21, Cases IV/33.440, 33.486.
} 
Table 2 Alleged economic conduct by decision type

\begin{tabular}{lccccr}
\hline & Negative clearance & Exemption & Infringement & Interim measure & Total \\
\hline Horizontal & 29 & 59.5 & 130.83 & 0 & 219.33 \\
Dominance & 1 & 0 & 45.33 & 3.5 & 49.83 \\
Licensing & 10.5 & 10 & 9.83 & 0.5 & 30.83 \\
Vertical & 24 & 32.5 & 66.5 & 1 & 124 \\
Joint venture & 11 & 49.5 & 2 & 0 & 62.5 \\
Article 86 & 0 & 5 & 16 & 0 & 21 \\
Procedural & 0 & 0 & 30.5 & 0 & 30.5 \\
Total & 75.5 & 156.5 & 301 & 5 & 538 \\
\hline
\end{tabular}

The hypothesis of independence between economic conduct and decision type is rejected at a one per cent significance level (Chi-square statistic is 183.789 with 18 d.f.)

If a decision involved more than one type of economic conduct, each of these received an equal share in the decision type. In total 12 decisions involved two different types of conduct. The only case causing a decision to be attributed to three different economic conducts is the Decca Navigator System Commission decision 89/113/EC [1989] OJ L 43/27, Cases IV/30.979, 31.394

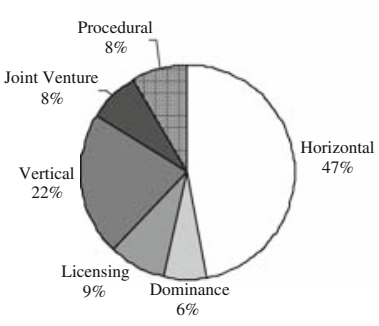

1964-77

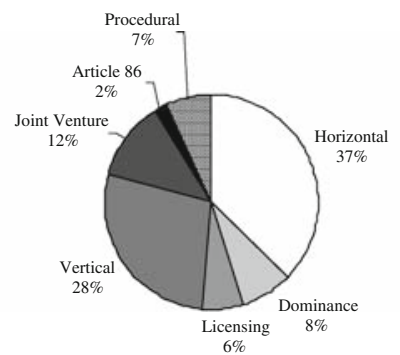

$1978-90$

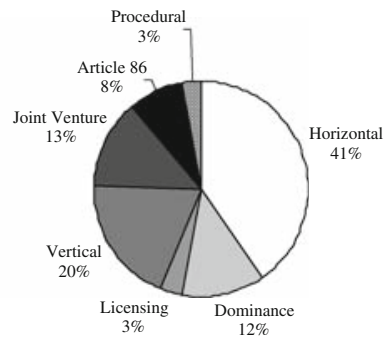

1991-04

Fig. 4 Formal Commission decisions by economic conduct per enforcement period

first cartel case (fined $€ 500,000$ ) and European Sugar, the largest cartel case in this period (a record breaking fine of $€ 9,000,000$ ). ${ }^{31}$ The category includes horizontal cooperative arrangements, such as trade associations, agreements on standards, and strategic alliances, many of which received a negative clearance or an exemption. More than 75 per cent of all horizontal infringement cases are cartel cases, concerned with fixing prices or dividing the market with the intent of eliminating competition. Whereas initially cartels were notified to the Commission, this quickly stopped, and cases were instead brought to the attention of the authorities through complaints or active detection by the Commission. In the last decade, almost all cartel investigations involved one or more leniency applications. ${ }^{32}$

Vertical restraints are the second largest category of formal decisions. They include territorial exclusivity agreements, selective distribution systems, exclusive dealing,

\footnotetext{
31 Quinine Commission decision 69/240/EEC [1969] OJ L 192/5, Case IV26.623; European sugar industry Commission decision 73/109/EC [1973] OJ L 140/17, Case IV/26.918.

32 Schinkel (2007) offers a more extensive analysis of European cartel cases.
} 
and franchising. The very first infringement found, in Grundig-Consten, was an exclusive dealing case. In the second period of enforcement, the share of vertical restraints in total is at its maximum with 28 per cent. Vertical restraints have a long history of block exemption regulations dating back to 1967 and renewed several times. ${ }^{33}$ The block exemption regulation introduced in June 2000 was designed to provide a "safe harbour' for most vertical agreements, in which market shares do not exceed 30 per cent. This possibly reduced the relative importance of vertical restraints in Fig. $4 .^{34}$ In the last decade, further efforts to integrate and harmonize the single European market have led to substantial fines for automobile manufacturers for preventing parallel imports: $€ 102$ million levied on VW-Audi, $€ 43$ million on Opel, and $€ 72$ million on Mercedes Benz. ${ }^{35}$

There has been a significant shift in the routes by which vertical cases have come to be considered by the European Commission. In the first enforcement period, almost 80 per cent of cases were notified by companies that sought permission for their business strategies. In the last period, no more than 15 per cent of decisions are the result of a notification, another 15 per cent follows from a complaint, and the other 70 per cent are classified as Commission's own initiative.

In total we identified seven subcategories that summarize the types of vertical restraints in the economic literature. They are: exclusive dealing and market foreclosure, territorial exclusivity and parallel import bans, resale price maintenance (RPM), bundling and tying, selective distribution systems, franchising, and discounts/rebates. Territorial exclusivity and parallel import bans form the largest category, constituting 50 per cent of all cases and 80 per cent of all infringements related to vertical restraints. This enforcement priority reinforces the aim of European market integration and harmonization that is explicit in the EC Treaty. Article 81(1) focuses on the prohibition of any conduct distorting internal EU market competition and trade.

All other sub-classifications are relatively small in size. The second and third largest categories are selective distribution systems and discounts/rebates, respectively. These two categories display a different pattern than the largest one, most often being concluded with an exemption or negative clearance. For selective distribution systems, only 15 per cent of all formal decisions are findings of an infringement, compared to 30 per cent that are negative clearances and 55 per cent that are exemptions. For discounts/rebates no infringements are recorded. Of all cases in this classification, 54 per cent received a negative clearance. To the others the temporary exemption from Article 81(3) applied. Hence, selective distribution systems appear not often perceived as harming competition to a sufficient extent to justify intervention. Discounts and rebates schemes only seem to raise competition concerns when a dominant position is present. However, there may be deterrence effects at work, including informal opposition by DG Comp, that do not appear in the numbers of formal decisions.

\footnotetext{
33 Commission Reg. 67/67/EEC of 22 March 1967 on the application of Article 85(3) of the Treaty to certain categories of exclusive dealing agreements.

34 Regulation No. 2790/1999, L336, 29.12.1999.

35 VW-Audi Commission decision 98/273/EC [1998] OJ L 124/60, Case IV/35.733; Opel Commission decision 2001/146/EC [2001] OJ L 59/1, Case COMP/36.653; Mercedes Benz Commission decision 2002/758/EC [2002] OJ L 257/1, Case COMP/36.264.
} 
The remaining four subcategories-exclusive dealing and market foreclosure, resale price maintenance, bundling and tying, and franchising - sum to 17 per cent of all decisions on agreements on vertical conduct. There have been only three decisions on exclusive dealing, all ending in a negative clearance. In contrast, RPM cases almost always resulted in an infringement. Only in one case, D'Ieteren motor oils, was a negative clearance granted. ${ }^{36}$ The Commission concluded that the benefits would be passed through to consumers in this case and did not intervene.

There are no vertical cases that prohibit bundling or tying. A negative clearance was given in 36 per cent of these cases. The rest were exemptions. Franchising agreements also found little resistance from the Commission. In a franchising agreement, all conditions covering distribution and production of a good are specified in detail. The franchisor limits the entrepreneurial freedom of the franchisee in return for the transfer of knowledge, trademarks, and/or patents. Still, the Commission did not perceive these limitations to be an issue and granted exemptions for all five franchise agreements that were under investigation. ${ }^{37}$ This was swiftly followed by the first block exemption regulation covering franchising agreements in $1988 .{ }^{38}$

Next, consider abuse of dominance decisions in Fig. 4. Their share increased somewhat in the third enforcement period, when the Commission made several landmark decisions, with the Microsoft case drawing the most attention. Other well known cases during this period are Tetra Pak II and Michelin.

We have distinguished ten economic sub-classifications of abuse of dominance: discriminatory sales conditions, predatory pricing, loyalty discounts/fidelity rebates, squeezing, bundling/tying, monopsony purchasing, restricting entry, refusal to sell/buy, preventing interoperability, and best-price guarantees. In many abuse cases, more than one potential form of anticompetitive behaviour plays a role.

In Tetra Pak II in 1991, for example, the company engaged simultaneously in discriminatory sales conditions, predatory pricing, tying, and restricting entry. The Commission fined the firm $€ 75$ million, the highest fine imposed under Article 82 at the time, against which Tetra Pak unsuccessfully appealed. ${ }^{39}$ Another example is the Irish Sugar decision in 1997, in which the company offered a complex discriminatory pricing and contract scheme that incorporated loyalty rebates that facilitated its attempt to price predatorily in order to restrict entry. The Commission imposed a fine of about $€ 9$ million, which was only slightly reduced on appeal. ${ }^{40}$ A more recent example is the Michelin case in 2002, in which Michelin was found to infringe EC

\footnotetext{
36 D'Ieteren motor oils Commission decision 91/39/EEC [1991] OJ L 20/42, Case IV/32.595.

37 These cases are: Yves Rocher Commission decision 87/14/EEC [1987] OJ L 8/49, Cases IV/31.428, 31.429, 31.430, 31.431, 31.432; Pronuptia Commission decision 87/17/EEC [1987] OJ L 13/39, Case IV/30.937; Computerland Commission decision 87/407/EEC [1987] OJ L 222/12, Case IV/32.034; Service Master Commission decision 88/604/EEC [1988] OJ L 332/38, Case IV/32.358; and Charles Jourdan Commission decision 89/94/EEC [1989] OJ L 35/31, Case IV/31.697.

38 Commission Reg. 4087/88/EEC of 28 December 1988 on the application of Article 85(3) of the Treaty to categories of franchise agreements.

39 Tetra Pak II Commission decision 92/163/EEC [1992] OJ L 72/1, Case IV/31.043.

40 Irish Sugar Commission decision 97/624/EC [1997] OJ L 258/1, Cases IV/34.621, 35.059.
} 
competition law for the second time on anticompetitive loyalty discounts and fidelity rebates. $^{41}$

Discriminatory sales conditions and refusal to sell/buy are the two most often found abuses of dominance, with 20 per cent each. An example of an early case of price discrimination with a substantial fine $(€ 1,000,000)$ was the Chiquita decision. ${ }^{42}$ Second are loyalty discounts, restricting entry, and best price guarantees, each accounting for about 15 per cent. There is no formal Commission decision that deals with monopsony purchasing power in the enforcement period that we consider. Aspects of bundling or tying are found in ten cases. There are only seven cases of predatory pricing in the period considered. The first was $A k z o / E C S$, in which an interim measure was decided in 1983 and a fine of $€ 10$ million was given in 1985. ${ }^{43}$ Akzo was accused of seeking to remove its British competitor ECS from the benzoyl peroxide market by anticompetitive means. There are three cases of price squeezing and two of preventing interoperability. The latter are Decca Navigator and Microsoft, of which Microsoft led to the then highest fine in an abuse of dominance case. The decision was unsuccessfully appealed to the CFI. ${ }^{44}$

Licensing and joint ventures together remained a steady category over the years of around 17 per cent of all decisions, mostly negative clearances and exemptions. Joint ventures increased somewhat in the total share of decision types, from seven to twelve and thirteen per cent over the enforcement periods. At the same time, licensing cases decreased from nine to six and four per cent.

Joint ventures (JVs) can be divided into those involving mainly R\&D and those involving mainly marketing, distribution, and production. The types of JVs show a dispersed pattern over time. In the first and the last enforcement period, marketing, distribution, and production agreements constituted about two-thirds of JV cases. In the intermediate period from 1978-1990, most JVs were concerned with R\&D agreements. Strategic alliances became increasingly popular as an alternative form of cooperation and a separate enforcement category from the mid 1990s onward, with a total of eight decisions until 2004. The alliances all received exemptions, which was consistent with the Commission's goal of strengthening the competitiveness of its Member State firms. All cases were brought to the attention of the Commission by notification.

For licensing, we distinguish trademark and branding, and intellectual property rights (IPR). Across all periods, IPR licensing was more frequent than trademark and branding licenses. Whereas from 1964 until 1990 IPR licensing constituted about two-thirds of all the cases, in the last enforcement period all licensing cases were IPR cases. Licensing cases were almost all the result of notifications and increasingly came under block exemption regulations.

\footnotetext{
41 Michelin Commission decision 2002/405/EC [2002] OJ L 143/1, Case COMP/E-2/36.041.

42 Chiquita Commission decision 76/353/EEC [1976] OJ L 95/1, Case IV/26.699.

43 Ecs/Akzo Chemie Commission decision 85/609/EEC [1985] OJ L 374/1, Case IV/30.698.

44 Decca Navigator System Commission decision 89/113/EC [1989] OJ L 43/27, Cases IV/30.979, 31.394; Microsoft Commission decision of 24 March 2004, published on DG Comp website, Case COMP/C3/37.792.
} 
Finally, note from Fig. 4 that the share of the Article 86 decisions (many made in conjunction with Article 82) is small but grows over time. The share is 8 per cent in the last period between 1991 and 2004. Prominent examples for the increased attention for former state-run monopolies being liberalized are UPS/Deutsche Post ${ }^{45}$, British Post/Deutsche Post, ${ }^{46}$ and Snepeld/La Poste. ${ }^{47}$ Five exemptions in 1996 and 1997 were addressed to Member States to exempt a postponement to liberalize their local telecommunications industries. ${ }^{48}$

\section{Commission Decisions by Economic Sector and Nationality}

The European Commission appears to have found more need for the application of the European competition rules in certain industries than in others. Amongst the horizontal cartel infringements, for example, many concern the chemical industry. Many vertical abuses were established in the automobile, cosmetics, consumer electronics, and alcoholic beverage industries. In this section, we consider the distribution of all antitrust decisions over ten sectors as specified by the OECD: agriculture; mining; manufacturing; electricity and gas; construction; trade (wholesaling and retailing) and hotels; transport; banking and insurance (including real estate); communication; and public service. We further subdivided the manufacturing sectors into five sub-sectors: food and drink; textile, leather, and paper; chemicals; plastics, rubber, and glass; and metal products and engineering (including cars and electronics).

Table 3 presents decisions categorized by sector. This table and the remainder of this paper concentrate on issues of economic conduct and therefore exclude the interim measure cases (5) and the procedural issue cases (30.5), leaving 502.5 cases. The largest number of antitrust decisions were in manufacturing, communication, and transport. Manufacturing alone accounts for more than six out of ten cases as well as infringements. This is clearly a very large sector that includes many large firms. It is also a sector with relatively high entry barriers, is generally capital intensive, and has important inter-firm dependencies-for example, through standards setting. This increases the risk of abuse and/or collusion relative to industries with lower barriers, lower capital intensity, and less R\&D expenditures.

The table reveals that there has been a relatively low share of infringement decisions in trade and hotels, as well as in banking and insurance. There were seven infringement decisions in the banking and insurance sector, including cartel cases of financial institutions that fixed inter-banking commission rates. However, banking also received a substantial number of exemption decisions on arrangements related to the develop-

\footnotetext{
45 Deutsche Post AG Commission decision 2001/354/EC [2001] OJ L 125/27, Case COMP/35.141.

46 Deutsche Post AG-Interception of cross-border mail Commission decision 2001/892/EC [2001] OJ L 331/40, Case COMP/C-1/36.915.

47 Snelpd/France, La Poste Commission decision 2002/344/EC [2002] OJ L 120/19, Case COMP/37.133.

48 The five countries addressed are Ireland, Portugal, Luxembourg, Spain, and Greece. The cases are grouped under Article 86 since addressed to Member States but actually fall under Commission Directive 90/338/EEC of 28 June 1990 on competition in the market for telecommunication services [1990] OL L 192/10 and Commission Directive 96/2/EC of 16 January 1996 amending Directive 90/338/EEC with regard to mobile and personal communications [1996] OJ L 20/59.
} 
Table 3 Decision by sector classification

\begin{tabular}{lcccc}
\hline & Negative clearance & Exemption & Infringement & Total \\
\hline Agriculture & 1 & 1 & 11 & 13 \\
Mining & 2.5 & 0 & 3.5 & 6 \\
Manufacturing & 91.5 & 39.5 & 176 & 307 \\
Food \& drinks & 6 & 3 & 31 & 40 \\
Textile, leather, \& paper & 5 & 3 & 8 & 16 \\
Chemicals & 24.5 & 11 & 49.5 & 85 \\
Plastics, rubber, \& glass & 8 & 7 & 34 & 49 \\
Metal products \& engineering & 48 & 15.5 & 53.5 & 117 \\
Electricity \& gas & 5 & 1 & 3 & 9 \\
Construction & 0 & 4 & 5 & 9 \\
Trade \& hotels & 6.5 & 14.5 & 9 & 30 \\
Transport & 9 & 2 & 30.5 & 41.5 \\
Banking \& insurance & 13.5 & 5.5 & 7 & 26 \\
Communication & 25.5 & 9 & 22.5 & 57 \\
Public service & 1 & 0 & 3 & 4 \\
Total & 155.5 & 76.5 & 270.5 & 502.5 \\
\hline
\end{tabular}

The hypothesis of independence between OECD sector and decision type is rejected at a one per cent significance level (Chi-square statistic is 65.717 with 18 d.f.)

Both an exemption and a negative clearance were given in eight cases. All decisions but four involved one sector only. These four cases involved two sectors

ment of payment networks. The transportation sector, on the other hand, has seen a high share of adverse findings. About three-quarters of all decisions are infringements in this sector. Transport has historically attracted a substantial amount of regulatory attention, for example with respect to maritime trade agency agreements. ${ }^{49}$ The Commission's interest in the communication sector is in part related to the liberalization efforts in this sector, for example in postal service.

Table 4 presents the OECD sector classification versus economic conduct. This break-down gives some insight into possible reasons for the differences in the rate of infringement across different sectors. The high rate in the transport sector appears due to a relatively large number of abuse of dominance issues. The low rate in the communication sector can be related to a relatively high number of joint ventures, a category that is usually exempted. Note that many Article 86 cases fall in this sector. Licensing and joint venture cases are relatively frequently found in the metal products and engineering sub-sector. Finally, the Commission discovered that a sizeable

\footnotetext{
49 Transatlantic Agreement Commission decision 94/980/EEC [1994] OJ L 376/1, Case IV/34.446, Greek Ferries Commission decision 1999/271/EC [1999] OJ L 109/24, Case IV/34.446, P\&I Clubs Commission decision 1999/329/EC [1999] OJ L 125/12, Case IV/30.373. See also Council Reg. 4056/86/EEC of 22 December 1986 laying down detailed rules for the application of Articles 85 and 86 of the Treaty to maritime transport.
} 
Table 4 Alleged economic conduct by sector classification

\begin{tabular}{|c|c|c|c|c|c|c|c|}
\hline \multirow[b]{2}{*}{ Agriculture } & \multicolumn{7}{|c|}{ Horizontal Dominance Licensing Vertical Joint venture Article 86 Total } \\
\hline & 7 & 1 & 2 & 3 & 0 & 0 & 13 \\
\hline Mining & 6 & 0 & 0 & 0 & 0 & 0 & 6 \\
\hline Manufacturing & 136.83 & 23.83 & 19.83 & 89.5 & 37 & 0 & 307 \\
\hline Food \& drinks & 17 & 3 & 5.5 & 14.5 & 0 & 0 & 40 \\
\hline Textile, leather, \& paper & 8 & 0 & 3 & 3 & 2 & 0 & 16 \\
\hline Chemicals & 51 & 8 & 1 & 13.5 & 11.5 & 0 & 85 \\
\hline Plastics, rubber, \& glass & 27 & 4 & 3 & 11 & 4 & 0 & 49 \\
\hline Metal products \& engineering & 33.83 & 8.83 & 7.33 & 47.5 & 19.5 & 0 & 117 \\
\hline Electricity \& gas & 2 & 1 & 2 & 2 & 2 & 0 & 9 \\
\hline Construction & 8 & 0 & 0 & 1 & 0 & 0 & 9 \\
\hline Trade \& hotels & 10 & 0 & 1.5 & 18.5 & 0 & 0 & 30 \\
\hline Transport & 18.5 & 10 & 0 & 2 & 4 & 7 & 41.5 \\
\hline Banking \& insurance & 21 & 1 & 0 & 2 & 1 & 1 & 26 \\
\hline Communication & 8.5 & 8.5 & 5.5 & 4 & 17.5 & 13 & 57 \\
\hline Public service & 2 & 1 & 0 & 1 & 0 & 0 & 4 \\
\hline Total & 219.83 & 46.33 & 30.83 & 123 & 61.5 & 21 & 502.5 \\
\hline
\end{tabular}

The hypothesis of independence between economic conduct and sector classification is rejected at a one per cent significance level (Chi-square statistic is 204.105 with 45 d.f.)

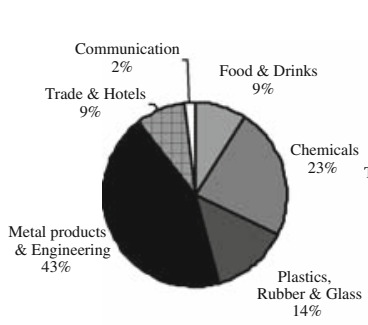

1964-77

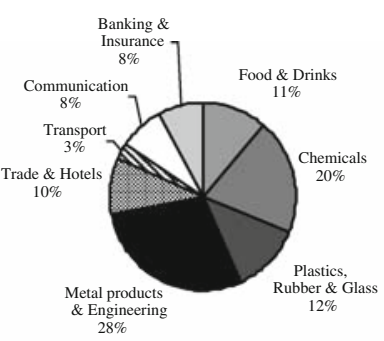

$1978-90$

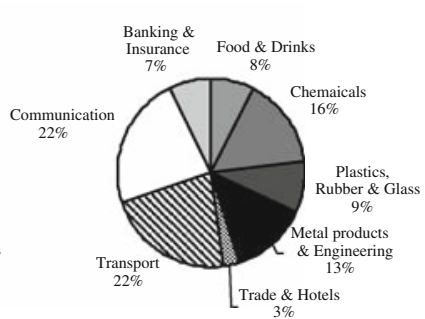

1991-04

Fig. 5 Commission decisions by eight main sectors per enforcement period

number of trade associations were facilitating price-fixing and bid-rigging cartels in the construction sector, especially in the Netherlands, Germany, and Belgium. ${ }^{50}$

We focus on the main eight sub-sectors: four sub-sectors of manufacturing; trade and hotels; banking and insurance; transportation; and communication. Together, these sectors contain the bulk of cases. In Fig. 5, the share of each sub-sector in formal Commission decisions for these eight sub-sectors is presented for the three enforcement periods. Manufacturing is the largest sector. However, its overall share of cases became less than half during the third enforcement period. The sub-sector of metal products and engineering has especially decreased in terms of the relative number of cases.

\footnotetext{
50 Starting with Vereeniging van Cementhandelaren Commission decision 72/22/EEC [1972] OJ L 13/34, Case IV/324 up to Stichting Certificatie Kraanverhuurbedrijf and FNK Commission decision 94/272/EEC [1994] OJ L 117/30, Case IV/B-2/34.179. An important bid-rigging case was Building and Constructions in the Netherlands Commission decision 92/204/EEC [1992] OJ L 92/1, Cases IV/31.571, 31.572.
} 
The sub-sector of chemicals continues to be sizeable in terms of the number of cases. This industry is prone to collusion, producing relatively homogeneous products in concentrated markets. It contains the bulk of repeat offenders in European antitrust. A list of the firms most often discovered violating the EC rules (usually in cartels) contains: BASF (involved in 9 infringement cases), Solvay (8), ICI (8), Hoechst/Aventis (8), ${ }^{51}$ AKZO (4), Bayer (4), and Shell (4). These firms were often found in cartels together, as in Dyestuffs, and later Polypropylene and $P V C .^{52}$ The discovered cartels in chemicals were very much interconnected, so that one revealed case could quickly lead to another. ${ }^{53}$ The leniency notice has also helped to uncover cartels in chemicals, but it appears that some other sectors are immune to leniency. ${ }^{54}$ The transportation and communication sectors show a steady increase in importance. Many of these decisions are Article 86 cases and relate to the liberalization processes in the various Member States.

Table 5 displays the countries from which the firms involved in the cases originate. The top five countries include four of the founding countries of the European Community (France, Germany, Belgium, and the Netherlands) together with the United Kingdom. The Netherlands ranks highest in the percentage of infringements among its total cases (71\%). This may be due to that country's not having had a competition authority until 1998. Many firms in the construction sector have, for example, been fined by the Commission. The lowest percentages of infringements are found for non-European countries, with the notable exception of Japan (63\%). France stands out among the large European countries with a relatively low percentage: $41 \%$. The Chi-square test confirms that there is no independence between countries and decision type.

\section{Enforcement of the Competition Rules}

Our data allow us to study the duration of the investigations of the European Commission in cases that reached the stage of a formal decision. Figure 6 shows the average case duration of cases opened in a given year, from the start of the investigation until production of the formal decision (in months per year). ${ }^{55}$

The figure clearly shows that early cases took (on average) very long. The average number of months of investigation dropped to an average of about thirty months per decision opened after 1975. Related to the duration of the investigation is the backlog of cases at DG Comp. During the 1970s, a backlog of about four thousand cases had accumulated, which was first reduced in the 1980s under Commissioner Sutherland. About one thousand cases were closed in a short period of time. ${ }^{56}$ This

\footnotetext{
51 Aventis is the name of the newly established company after Hoechst and Rhône-Poulenc merged.

52 Polypropylene Commission decision 86/398/EEC [1986] OJ L 230/1, Case IV/31.149 and PVC Commission decision 89/190/EEC [1989] OJ L 74/1, Case IV/31.865.

53 See Stephan (2005).

54 See Roeller and Stehmann (2006, p. 293).

55 This is the only figure that ranks cases according to the opening date instead of the decision date.

56 See XV Report on Competition 1985, p. 38.
} 
Table 5 Nationality of firms by decision type

\begin{tabular}{lcccr}
\hline & Negative clearance & Exemption & Infringement & Total \\
\hline Germany & 23 & 158 & 300 & 481 \\
France & 83.5 & 148.5 & 164 & 396 \\
Belgium & 49 & 30 & 157 & 236 \\
Netherlands & 24.5 & 69.5 & 227 & 321 \\
Italy & 8 & 46 & 72 & 126 \\
Spain & 2 & 25 & 33 & 60 \\
UK & 40 & 151 & 160 & 351 \\
Scandinavia & 12 & 77 & 85 & 174 \\
Other European Countries & 12 & 114 & 78 & 204 \\
US and Canada & 31 & 98 & 48 & 177 \\
South America & 2 & 56 & 14 & 72 \\
Africa & 0 & 58 & 21 & 79 \\
Russia, Asia and Australia & 4 & 149 & 38 & 83 \\
Japan & 2.5 & 28.5 & 52 & 2951 \\
Total & 293.5 & 1208.5 & 1449 & 191 \\
\hline
\end{tabular}

The hypothesis of independence between nationality and decision type is rejected at a one per cent significance level (Chi-square statistic is 503.906 with 26 d.f.)

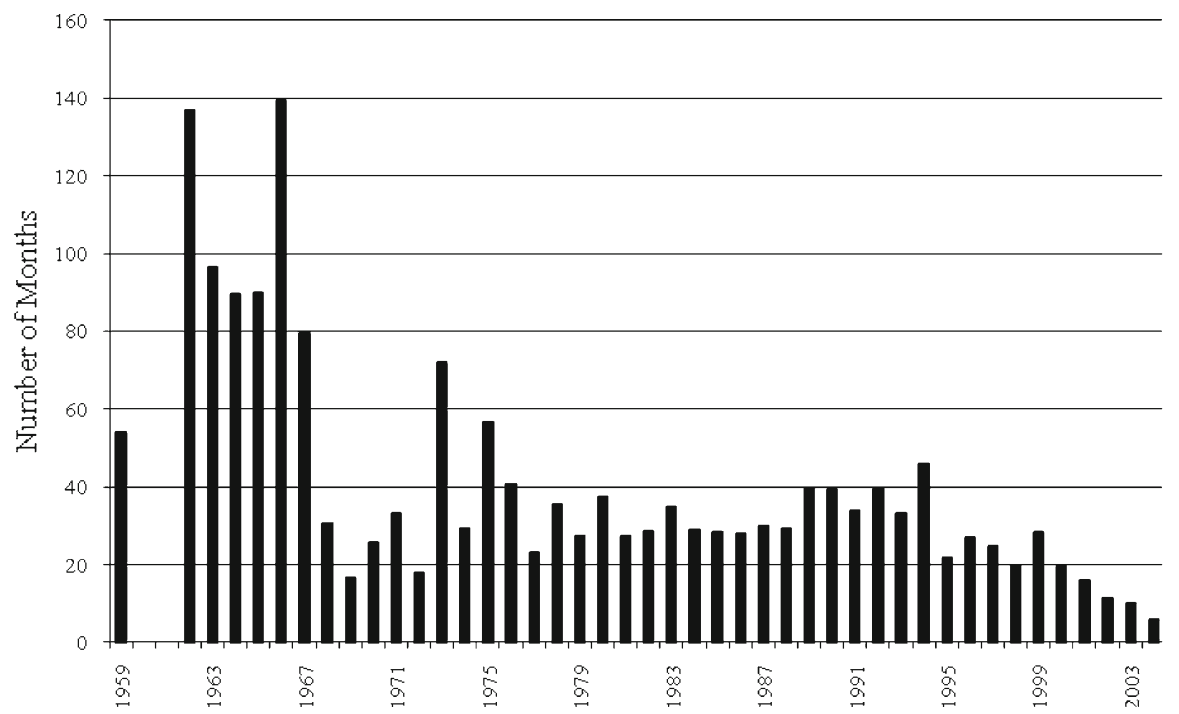

Fig. 6 Duration of antitrust investigations, by year of initiation

was in part because notified agreements had expired and the introduction of block exemption regulations had made new notifications unnecessary. Thereafter, there was a rapid decline of the backlog under Commissioner Brittan until 1992, when the stock of investigations was around one thousand. ${ }^{57}$

\footnotetext{
57 See XXII Report on Competition 1992, p. 83.
} 
Of all Article 81 and 82 decisions, the longest investigation period of all Commission decisions has been in Association Belge des Banques (1986): 289 months. ${ }^{58}$ However, the long duration of the case is best explained by the backlog effect. The Association of Belgium Banks filed a notification in 1962, but was apparently only investigated more than two decades later under Commissioner Sutherland. DG Comp did not give such older cases priority and focused its limited resources on more critical cases. Two cases were decided upon exceptionally quickly (i.e., within one month): NAVEWA-ANSEAU and EATA. ${ }^{59}$ On average over all its formal decisions, the Commission needed 40.6 months to reach a conclusion after opening an investigation, with an average of 43 months for Article 81 and 30 months for Article 82 decisions.

Another statistic that conveys information about the enforcement process is the written length of a decision, which is measured as the number of recitals in the official publication. The formal decision documents are organized in numbered paragraphs, each containing a more-or-less self-contained element of the analysis - such as a separate argument. Therefore, the length of the decisions in terms of their paragraphs conveys some information on the extent of the analysis and the complexity of the case. The longest Commission decision on Article 81 in terms of recitals was the Copper Plumbing Tubes cartel: 842 recitals. ${ }^{60}$ For Article 82, the longest was Microsoft: 1080 recitals. ${ }^{61}$ Overall, decisions required 82 recitals on average. Figure 7 plots the average number of recitals per decision per year and reveals an exponential growth.

All cases after July 2001 have required more than 90 recitals. This can only partly be related to the increasing percentage of infringements (compare with Fig. 2). In 2002 and 2004, the average length of the official decisions is above 300 recitals, with some complex cases, such as Plasterboard with 601 recitals and the Microsoft case with 1080 recitals. ${ }^{62}$ Cartel cases in particular tend toward long decision documents, even when their investigation time is relatively short. The number of recitals in Fine Art Auction Houses, which took only half a year to conclude, for example, is 238.63 The Commission has a tendency to justify Article 81 and 82 cases in roughly equally extensive terms. For the period 2001-2004 the average length was 293 recitals for Article 81 cases and 273 recitals for Article 82/86 cases. The latter, however, includes the large Microsoft case.

The European Commission is expected to justify its infringement decisions in detail. Several successful appeals to the courts in the 1990s have raised requirements in terms of the precision of the factual description and in terms of the economic and legal argumentation made by the Commission. Thus, the then newly established CFI left its mark. In addition, the average number of recitals has probably increased due to a selection

\footnotetext{
58 Association Belge des Banques Commission decision 87/13/EEC [1987] OJ L 7/27, Case IV/261.

59 Navewa-Anseau Commission decision 82/371/EEC [1982] OJ L 167/17, Case IV/29.995; Europe Asia Trade Agreement Commission decision 1999/485/EC [1999] OJ L 193/23, Case IV/34.250.

60 Industrial copper tubes Commission decision 2004/421/EC [2004] OJ L 125/50, Case COMP/38.240.

61 Microsoft Commission decision of 24 March 2004, published on DG Comp website, Case COMP/C$3 / 37.792$.

62 Plasterboard Commission decision 2005/471/EC [2005] OJ L 166/8, Case COMP/E-1/37.152.

63 Fine Art Auction Houses Commission decision 2005/590/EC [2005] OJ L 200/92, Case COMP/E$2 / 37.784$.
} 


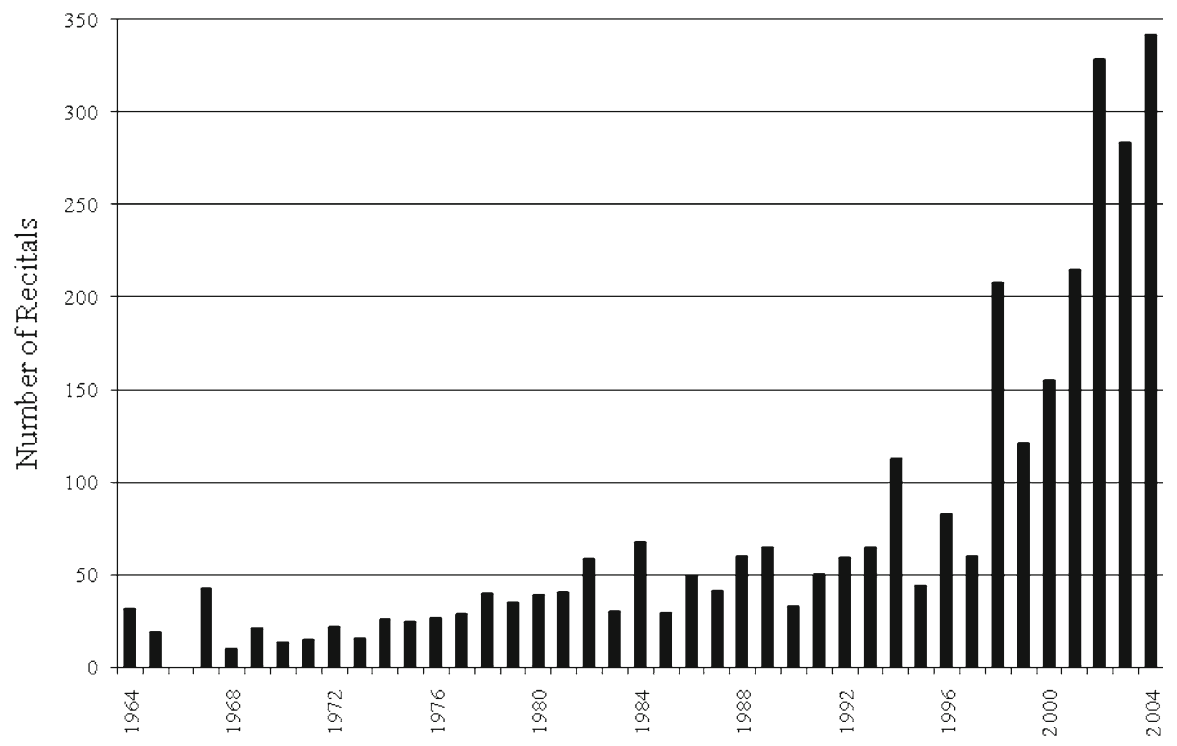

Fig. 7 Average number of recitals per decision per year

bias, as in recent years the Commission almost exclusively publishes infringements, as opposed to negative clearances, which can be much shorter. Since 1998, the average number of recitals has been successively higher for each subsequent year. This may be caused by the introduction of fining guidelines in 1998, which required more elaborate justification. ${ }^{64}$ In addition, the leniency applications often result in large amounts of important evidence, which support the detail in decision documents. The two trends of shortened investigation times and more extensive decision documents also relate to an increase in DG Comp's staff numbers and in their experience and expertise.

Each official decision is signed by a Member of the Commission. In the period up to July 1975 this was the President of the European Commission, and thereafter it was the Commissioner for Competition. Albert Borschette was the first Commissioner for Competition to sign decisions (in the last year of his period in office). Raymond Vouel was the first to sign all decisions during his period as Commissioner for Competition. In our sample period, in total 15 different Members of the Commission have signed one or more decisions. In Table 6 we give an overview of the decisions signed by the President or the Commissioner for Competition.

The first President, Walter Hallstein, signed only nine cases, finding one single infringement. Yet, as explained above, in the initial years of the enforcement of the Treaty of Rome, emphasis was on establishing the tools for enforcement of the Treaty, producing a number of Regulations. Peter Sutherland and Mario Monti were the most active Commissioners, according to the decisions/month measure. There has been an

\footnotetext{
64 Fining guidelines were published on 14 January 1998, OJ C 9/3. The guidelines show how the amount of a fine is determined from a basic amount that is increased due to aggravating circumstances and decreased due to attenuating circumstances.
} 
Table 6 Antitrust decisions per Commissioner's period in office

\begin{tabular}{llcccl}
\hline Signer & Period in office & Months & Decisions & Infringements & Decisions/month \\
\hline Walter Hallstein $^{\mathrm{a}}$ & $01 / 58-06 / 67$ & 113 & 9 & 1 & 0.08 \\
Jean Rey $^{\mathrm{b}}$ & $06 / 67-06 / 70$ & 36 & 21 & 2 & 0.58 \\
Franco Malfatti $^{\mathrm{c}}$ & $06 / 70-03 / 72$ & 21 & 18 & 6 & 0.86 \\
Sicco Mansholt $^{\mathrm{d}}$ & $03 / 72-01 / 73$ & 10 & 10 & 8 & 1.00 \\
Francois-Xavier Ortoli $^{\mathrm{e}}$ & $01 / 73-07 / 76$ & 42 & 26 & 15 & 0.58 \\
Raymond Vouel $_{\text {Frans Andriessen }}$ & $07 / 76-01 / 81$ & 54 & 49.5 & 32.5 & 0.92 \\
Peter Sutherland & $01 / 81-01 / 85$ & 48 & 55 & 33 & 1.15 \\
Leon Brittan & $01 / 85-01 / 89$ & 48 & 77 & 30 & 1.60 \\
Karel Van Miert & $01 / 99-01 / 93$ & 48 & 62 & 35 & 1.29 \\
Mario Monti & $09 / 99-11 / 04^{\mathrm{f}}$ & 50 & 86 & 41 & 1.08 \\
\hline
\end{tabular}

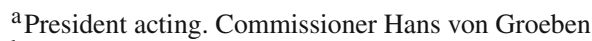

${ }^{\mathrm{b}}$ President acting. Commissioner Maan Sassen

$\mathrm{c}, \mathrm{d}$, e President acting. Commissioner Albert Borschette

${ }^{\mathrm{f}}$ Monti left office in November 2004, being succeeded by Commissioner Kroes

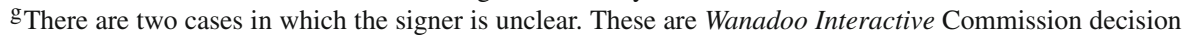
of 16 July 2003, case COMP/38.233 and Compagnie Maritime Belge (CEWAL) Commission decision of 30 April 2004, cases COMP/D/32.448, 32.450. We have assumed that both cases were signed by Commissioner Mario Monti

We do not incorporate the following Members of the Commission signing: A. Borschette ( 8 non-procedural decisions), P.J. Hillery (1), and G.M. Thomson (2)

The hypothesis of independence between Commissioner and share of infringements is rejected at a one per cent significance level (Chi-square statistic is 27.597 with 10 d.f.)

end-of-term effect for some Commissioners. Commissioners Andriessen, Sutherland, and Brittan had each almost thirty per cent of their decisions taken in the last six months of their term. We find no such effect for the latest two Commissioners, Van Miert and Monti. The share of infringements has increased considerably in the Monti period. The latter is confirmed by the Chi-square test.

Table 7 presents a similar assignment of formal decisions to the Director Generals of DG Comp. Again, in the initial decade under Pieter VerLoren van Themaat, the Directorate General produced only a few decisions. Since the early 1980s, however, when Manfred Caspari took office, output per month is almost constant at about one per month. Note that Philip Lowe remained in office after the end of our sample period in December 2004.

\section{Remedies and Sanctions}

In total, there are 301 infringements decisions, including 30 purely procedural cases further neglected. ${ }^{65}$ In the first period between 1964 until 1977, the Commission

\footnotetext{
65 Fines for procedural violations, such as a failure to provide requested information, are relatively small. The only case that has a procedural and an economic concern is the Theal/Watts case. Theal/Watts
} 
Table 7 Antitrust decisions per Director General's period in office

\begin{tabular}{lccccc}
\hline Director General & Period in office & Months & Decisions & Infringements & Decisions/month \\
\hline Pieter VerLoren van Themaat & $04 / 58-09 / 67$ & 113 & 9 & 1 & 0.08 \\
Ernst Albrecht & $10 / 67-12 / 70$ & 39 & 25 & 4 & 0.64 \\
Willy Schleider & $01 / 71-04 / 81$ & 124 & 110.5 & 65.5 & 0.89 \\
Manfred Caspari & $05 / 81-12 / 89$ & 105 & 144 & 67 & 1.37 \\
Claus Dieter Ehlermann & $03 / 90-04 / 95$ & 61 & 81 & 44 & 1.33 \\
Alexander Schlaub & $05 / 95-08 / 02$ & 88 & 96 & 61 & 1.09 \\
Philip Lowe & $09 / 02-12 / 04$ & 28 & 37 & 28 & 1.32 \\
\hline
\end{tabular}

The hypothesis of independence between Director General and share of infringements is rejected at a five per cent significance level (Chi-square statistic is 16.698 with 6 d.f.)

produced 61 infringement decisions. The second period, 1978-1990, accounts for 108 cases and the last, 1991-2004, for 132. The two joint ventures-out of more than 60 applications - that were formally concluded to be a breach of Article 81 are excluded from our analysis in this section. They were not fined, and neither decision was appealed.

There are four main categories of infringements: horizontal constraints; abuse of dominance (Articles 82 and 86); vertical restraints; and licensing. Most infringements in the last enforcement period are in the category of horizontal constraints. Apart from an increased priority for cartel enforcement, this may reflect the success of the leniency programs in attracting applications. Between 1991 and 2004, almost 40 per cent of horizontal infringement decisions resulted from investigations that involved one or more leniency applications. The category of licensing infringements almost vanished over time. In the latest period, there was only one infringement involving an aspect of licensing. ${ }^{66}$ This may reflect the Commission's recognition of the importance of technology and trademark transfers. ${ }^{67}$

The Commission can penalize infringements of the EC competition rules. Normally, the Commission would order the infringing parties to discontinue their anti-competitive behaviour. In addition, the Commission can impose sanctions in the form of fines, as well as structural and behavioural remedies. We focus on the use and level of fines. Both have increased over the history of European competition law enforcement. Figure 8 shows the average fine per antitrust infringement with a fine over the years, corrected for inflation. ${ }^{68}$ Clearly, average fines have increased drastically in real value over the years. This reflects the European Commission's commitment to enforce competition rules.

\section{Footnote 65 continued}

Commission decision 77/129/EEC [1977] OJ L 39/19, Case IV/28.812. The case involved a vertical agreement preventing parallel imports that was notified, but with incorrect information about the underlying agreement. The two companies were fined $€ 25,000$ for procedural errors, and the agreement was prohibited.

66 Souris-Topps Commission decision of 26 May 2004 COMP/C-3/37.980 OJ L 353/5.

67 See Jorde and Teece (1990) and Korah (2001) for the relation between antitrust and IPR.

68 To correct for inflation, we used the official data from EUROSTAT. We used inflation rates over the years to express all fines in terms of Euros (ECU) of 2004. 


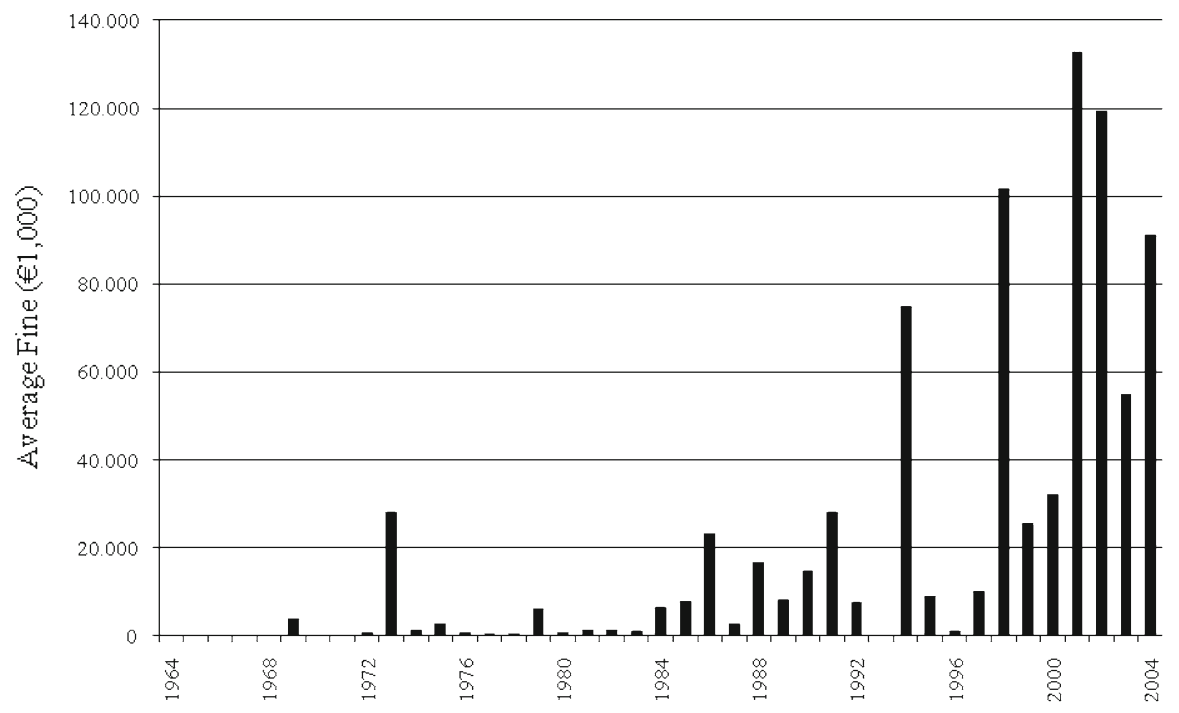

Fig. 8 Average total fines per antitrust infringement with a fine (in $€ 1,000$ of 2004)

The level of fines varies greatly over the types of infringement. The highest fine that the European Commission gave for an infringement of the competition rules for a single firm in a single case in our sample period was $€ 497.2$ million for the Microsoft Corporation in 2004. All other fines among the ten highest European Commission antitrust fines were for cartel cases. The highest fine for a case was $€ 855$.2 million for the Vitamins cartel case in $2001{ }^{69}$ From 1991 to 2004, all horizontal infringements have led to the imposition of a fine.

Table 8 presents (inflation corrected) fines according to the economic conduct for the three enforcement periods. The table presents the sum of fines, as well as the average fine per firm per infringement with a fine in that period. Note that Article 86 cases, involving a Member State or a company in charge of a service of general economic interest on behalf of the Member State, have never been fined and are excluded from the table. The category of horizontal conduct is responsible for the highest share (77 per cent) of total fines. The highest average fine per firm per infringement is for the categories of horizontal conduct (cartels) and abuse of dominance. These two types of infringements are clearly perceived as most harmful for economic welfare.

We seek to obtain insight into the determinants of the fine, both the fine per case and the fine per firm. ${ }^{70}$ To that end, we have estimated a regression model on 267 antitrust infringement decisions (excluding joint venture and procedural cases). ${ }^{71} \mathrm{We}$ also estimate the model for the fine imposed on the 1435 individual firms that were

\footnotetext{
69 Vitamins Commission decision 2003/2/EC [2003] OJ L 6/1, Case COMP/E-1/37.512.

70 See also Gallo et al. (2000) analyzing fines imposed by the US. Department of Justice and Connor (2006) contrasting fines imposed on cartels by different jurisdictions.

71 One case is excluded since we do not have information on the number of recitals since the decision document is not published yet. The case, Sodium gluconate Commission decision of 2 October 2001, Case COMP/36.756, was withdrawn on 19 March 2002, but only for one out of six cartel members. Also the Jungbuzlauer follow-up case is excluded.
} 
Table 8 Fines per type of economic conduct (in $€ 1,000$ of 2004) per enforcement period

\begin{tabular}{cllll}
\hline & Horizontal & Dominance & Licensing & Vertical \\
\hline Sum of fines & \multicolumn{5}{c}{} & & \\
$1964-1977$ & 26,975 & 4,203 & 0 & 1,289 \\
$1978-1990$ & 486,063 & 132,824 & 361 & 38,352 \\
$1991-2004$ & $6,593,378$ & $1,258,553$ & 1,176 & 708,571 \\
Average fine per case per firm & & & \\
$1964-1977$ & 115.1 & 277.4 & 0 & 32.3 \\
$1978-1990$ & $5,543.1$ & $9,915.2$ & 7.0 & $1,316.8$ \\
$1991-2004$ & $72,204.2$ & $74,681.1$ & 16.9 & $31,570.3$ \\
\hline
\end{tabular}

involved in these infringement cases. The dependent variable is $\log (\mathrm{fine}+1)$ where fine is inflation corrected. This functional form allows for incorporating all infringements, including those without fines, while also limiting the influence of the largest fines. Independent variables include case characteristics, sub-sector dummy variables (the five smallest sectors constitute the excluded category), and Commissioner dummy variables (the Commissioners before Vouel are the excluded category). The latter also act as time dummy variables. We include the nationality of the firm for the model with individual firm data (the excluded category is Oceania and Asia, apart from Japan). We include the following case characteristics: number of parties, duration, and the number of recitals. The latter is expressed as $\log$ (recitals) to adjust for its exponential growth over the years. For economic rationale we include a horizontal conduct dummy variable and an abuse of dominance (Article 82 and 86 cases) dummy variable, with vertical and licensing infringements being the excluded category. The linear regression results are given in Table 9.

The results indicate that fines are relatively high in manufacturing industries, especially in chemicals and metal products and engineering. The transport and communication sectors have relatively low fines as a result of proportionally many Article 86 infringements without fines. Fines increase over time, which is visible from the coefficient for the Monti period being highest. The number of recitals is positively related to the fine: the Commission will make a detailed case description presenting evidence of misconduct when it seeks to issue high fines. The duration of the case has a negative impact on the size of the fine, if any. Apparently, less critical cases have received less priority. The fine per firm is larger for abuse of dominance cases than for horizontal constraints or vertical restraint and licensing cases. ${ }^{72}$ Corporations from non-European countries tend to receive relatively low fines.

\section{Appeals before the CFI and the ECJ}

The formal decisions of the European Commission can be appealed before the European Court of Justice. ${ }^{73}$ Since 1989, for decisions adopted under EC competition rules,

\footnotetext{
72 The lack of significance for horizontal constraint cases is not due to a high correlation with the number of parties. The correlation coefficient is only 0.37 for cases and 0.25 for firm data.

73 There is an extensive literature on antitrust litigation versus settlement in the U.S. Examples are Priest and Klein (1984) and Perloff et al. (1996). European antitrust law enforcement deviates from U.S. practice.
} 
Table 9 Regression results for determinants of the fine per case and per firm

\begin{tabular}{|c|c|c|c|c|c|c|}
\hline \multirow[t]{2}{*}{ Variable } & \multicolumn{3}{|c|}{ Cases $(n=267)$} & \multicolumn{3}{|c|}{ Firms $(n=1435)$} \\
\hline & Coef & Error & Mean & Coef & Error & Mean \\
\hline Food \& drinks & $2.875^{*}$ & 1.746 & 0.116 & $1.216^{*}$ & 0.710 & 0.146 \\
\hline Textile, leather, \& paper & $4.613^{*}$ & 2.642 & 0.030 & 0.410 & 0.845 & 0.058 \\
\hline Chemicals & $5.310^{* * *}$ & 1.603 & 0.176 & $3.402^{* * *}$ & 0.680 & 0.134 \\
\hline Plastics, rubber, \& glass & $4.268^{* *}$ & 1.740 & 0.127 & $1.776^{* * *}$ & 0.636 & 0.235 \\
\hline Metal products \& engineering & $3.384^{* *}$ & 1.621 & 0.200 & $3.041^{* * *}$ & 0.695 & 0.130 \\
\hline Trade \& hotels & -0.986 & 2.620 & 0.034 & $2.861^{* * *}$ & 0.930 & 0.063 \\
\hline Transport & -0.059 & 1.876 & 0.114 & $-1.602^{* *}$ & 0.761 & 0.108 \\
\hline Banking \& insurance & 0.313 & 2.775 & 0.026 & 1.805 & 1.335 & 0.015 \\
\hline Communication & -2.655 & 2.035 & 0.081 & $-3.240^{* * *}$ & 0.985 & 0.032 \\
\hline Vouel & -2.012 & 1.622 & 0.116 & 0.577 & 0.535 & 0.180 \\
\hline Andriessen & 1.966 & 1.652 & 0.124 & 0.066 & 0.613 & 0.130 \\
\hline Sutherland & $2.777^{*}$ & 1.682 & 0.116 & $5.029^{* * *}$ & 0.735 & 0.063 \\
\hline Brittan & 1.475 & 1.683 & 0.127 & $4.851^{* * *}$ & 0.657 & 0.107 \\
\hline van Miert & 1.394 & 1.870 & 0.154 & $6.651^{* * *}$ & 0.746 & 0.148 \\
\hline Monti & $4.091^{* *}$ & 1.992 & 0.221 & $7.630^{* * *}$ & 0.810 & 0.159 \\
\hline Number of parties & 0.062 & 0.052 & 5.521 & 0.012 & 0.011 & 19.168 \\
\hline Duration & $-0.019^{*}$ & 0.010 & 37.169 & $-0.027^{* * *}$ & 0.004 & 40.333 \\
\hline Recitals & $2.552^{* * *}$ & 0.568 & 4.226 & $1.387^{* * *}$ & 0.223 & 4.335 \\
\hline Horizontal & -0.088 & 1.092 & 0.486 & -0.038 & 0.462 & 0.770 \\
\hline Dominance & 0.538 & 1.322 & 0.230 & $3.463^{* * *}$ & 0.795 & 0.057 \\
\hline Germany & & & & $1.752^{*}$ & 0.961 & 0.206 \\
\hline France & & & & $2.837^{* * *}$ & 0.999 & 0.111 \\
\hline Belgium & & & & $2.812^{* * *}$ & 0.994 & 0.109 \\
\hline Netherlands & & & & $1.677^{*}$ & 0.986 & 0.156 \\
\hline Italy & & & & $2.413^{* *}$ & 1.092 & 0.050 \\
\hline Spain & & & & 0.248 & 1.276 & 0.023 \\
\hline UK & & & & 0.116 & 0.981 & 0.111 \\
\hline Scandinavia & & & & 0.466 & 1.055 & 0.059 \\
\hline Other European Countries & & & & 0.723 & 1.054 & 0.054 \\
\hline US and Canada & & & & $-3.427^{* * *}$ & 1.184 & 0.033 \\
\hline South America & & & & -2.322 & 1.636 & 0.010 \\
\hline Africa & & & & $-3.365^{* *}$ & 1.452 & 0.015 \\
\hline Japan & & & & -0.045 & 1.158 & 0.036 \\
\hline Constant & $-5.826^{* *}$ & 2.387 & 1.000 & $-4.960^{* * *}$ & 1.365 & 1.000 \\
\hline
\end{tabular}

Mean dependent variables are 8.707 and 6.191 for Cases and Firms, respectively

Adjusted $\mathrm{R}^{2}$ are 0.358 and 0.452 for cases and firms, respectively

$*, * *, * * *$ Significance at the 10,5 , and $1 \%$ significance levels, respectively 
firms can appeal a Commission decision first before the CFI. In total 161 cases out of 538 formal Commission decisions have been appealed. There were appeals of slightly more than half (138) of the 267 Commission's infringement decisions. ${ }^{74}$ Appeals are by individual parties, so there may be several per decision. We record all appeals that were decided by CFI/ECJ. The total number of appeals decided was 503, with 13 pending. The two cases with the most appeals lodged were the BMW Belgium vertical restraints case (all 48 distributors appealed) and the Cement cartel (41 appeals). ${ }^{75}$

Article 82 decisions are appealed most often: in 66 per cent of all such cases. Cartel infringements follow closely: 54 per cent are appealed. The appeals rate has increased considerably among the recent cartel cases under the leniency notice: 25 out of 29 cases were appealed. This high appeals rate may also relate to the high fines that were given after the 1998 fines guidelines were introduced. The steep increase in cartel fines in this period provides a strong financial incentive to argue cases before the CFI. Out of the total of 503 appeals, 258 were completely upheld by CFI/ECJ, 158 were partially annulled or received fine reductions, and in 87 appeals the European Commission decision was quashed. An infamous case was the German Banks cartel, which was fined $€ 100.8$ million in total. ${ }^{76}$ In this case, the Commission had failed to meet its deadline by accidentally faxing its decision documents blank-side-up, which forced the court to rule in favour of the defendants and overturn the fines. The average received percentage of fine reduction (if any) for partially or fully annulled cases was 45 per cent.

We seek to obtain insight into the determinants of the appeal probability. To that end, we have estimated a probability model on the same 267 antitrust infringement decisions and 1435 firms as in Sect. 7. The appeal probability indicates the degree to which firms disagree with the infringement decision and this may differ across sectors, over time, across economic rationales, and with the complexity of the case at hand. We use a probit model with the binary outcome variable appeal, with 1 meaning there was (at least one) appeal to the case, otherwise 0 . We include the same independent variables as in Table 9. However, we add the average fine (per firm) and, for the firmlevel regressions, a dummy variable that indicates whether other firms have appealed in the same case.

Table 10 provides the probit results. If we denote our vector of independent vectors as $x$ and the corresponding vector of coefficients as $b$, then the equation for our model is: $P[$ appeal $=1]=\Phi\left(x^{T} b\right)$, where $\Phi$ is the cumulative normal distribution function. The marginal effect of $x$ on the probability is calculated as $d \Phi\left(x^{T} b\right) / d x$.

Table 10 provides marginal effects, coefficients, their standard errors, and the means of the independent variables. The Commissioner dummy variables do not display a clear pattern over time. This suggests that the rate of appeal has not been affected by

\footnotetext{
Footnote 73 continued

The Commission decision is taken under administrative law and, hence, there is only court involvement (litigation) when firms later appeal.

74 We ignore (the 19) appeals to exemptions and negative clearances in this section.

75 BMW Belgium NV and Belgian BMW dealers Commission decision 78/155/EEC [1978] OJ L 46/33, Case IV/29.146; Cement Commission decision 94/815/EEC [1994] OJ L 343/1, Case IV/33.126 and IV/33.322.

76 German Banks Commission decision 2003/25/EC [2003] OJ L15/1 Case COMP/37.919.
} 
Table 10 Probit results of the determinants of the probability of appeal

\begin{tabular}{|c|c|c|c|c|c|c|c|c|}
\hline \multirow[t]{2}{*}{ Variable } & \multicolumn{4}{|c|}{ Cases $(n=267)$} & \multicolumn{4}{|c|}{ Firms $(n=1435)$} \\
\hline & Marginal & Coef & Error & Mean & Marginal & 1 Coef & Error & Mean \\
\hline Food $\&$ drinks & 0.027 & 0.069 & 0.381 & 0.116 & 0.016 & 0.042 & 0.235 & 0.146 \\
\hline Textile, leather, \& paper & $r-0.094$ & -0.238 & 0.591 & 0.030 & -0.169 & $-0.470^{*}$ & 0.281 & 0.058 \\
\hline Chemicals & 0.163 & 0.421 & 0.361 & 0.176 & -0.224 & $-0.577^{* *}$ & 0.233 & 0.134 \\
\hline Plastics, rubber, \& glass & 0.008 & 0.020 & 0.402 & 0.127 & -0.214 & $-0.552^{* *}$ & 0.225 & 0.235 \\
\hline $\begin{array}{l}\text { Metal products \& } \\
\text { Engineering }\end{array}$ & -0.083 & -0.208 & 0.357 & 0.200 & -0.263 & $-0.678 * * *$ & 0.252 & 0.130 \\
\hline Trade \& hotels & -0.277 & -0.696 & 0.631 & 0.034 & -0.093 & -0.239 & 0.342 & 0.063 \\
\hline Transport & -0.144 & -0.362 & 0.404 & 0.114 & -0.084 & -0.216 & 0.258 & 0.108 \\
\hline Banking \& insurance & 0.341 & 1.034 & 0.665 & 0.026 & 0.146 & 0.369 & 0.432 & 0.015 \\
\hline Communication & 0.036 & 0.090 & 0.433 & 0.081 & -0.031 & -0.081 & 0.334 & 0.032 \\
\hline Vouel & -0.144 & -0.364 & 0.367 & 0.116 & 0.270 & $0.690^{* * *}$ & 0.207 & 0.180 \\
\hline Andriessen & -0.105 & -0.265 & 0.364 & 0.124 & -0.042 & -0.111 & 0.229 & 0.130 \\
\hline Sutherland & -0.114 & -0.288 & 0.375 & 0.116 & 0.115 & 0.292 & 0.250 & 0.063 \\
\hline Brittan & 0.019 & 0.047 & 0.376 & 0.127 & -0.080 & -0.213 & 0.236 & 0.107 \\
\hline van Miert & -0.030 & -0.076 & 0.422 & 0.154 & 0.301 & $0.775^{* * *}$ & 0.277 & 0.148 \\
\hline Monti & -0.169 & -0.427 & 0.453 & 0.221 & -0.063 & -0.166 & 0.287 & 0.159 \\
\hline Average party fine & 0.027 & $0.068^{* * *}$ & 0.014 & 8.707 & 0.027 & $0.070^{* * *}$ & 0.009 & 6.191 \\
\hline Number of parties & 0.009 & $0.023^{* *}$ & 0.012 & 5.521 & 0.004 & $0.011^{* * *}$ & 0.004 & 19.168 \\
\hline Duration & 0.002 & 0.004 & 0.002 & 37.169 & 0.000 & 0.000 & 0.002 & 40.333 \\
\hline Recitals & 0.166 & $0.417^{* * *}$ & 0.134 & 4.226 & -0.008 & -0.021 & 0.084 & 4.335 \\
\hline Horizontal & -0.054 & -0.136 & 0.240 & 0.486 & -0.066 & -0.171 & 0.158 & 0.770 \\
\hline Dominance & 0.196 & $0.494^{*}$ & 0.294 & 0.230 & 0.443 & $1.143^{* * *}$ & 0.256 & 0.057 \\
\hline Other company appeals & & & & & 0.735 & $2.262^{* * *}$ & 0.127 & 0.473 \\
\hline Germany & & & & & 0.290 & $0.745^{* *}$ & 0.330 & 0.206 \\
\hline France & & & & & 0.161 & 0.409 & 0.339 & 0.111 \\
\hline Belgium & & & & & 0.268 & $0.686^{* *}$ & 0.351 & 0.109 \\
\hline Netherlands & & & & & 0.282 & $0.722^{* *}$ & 0.338 & 0.156 \\
\hline Italy & & & & & 0.260 & $0.665^{*}$ & 0.379 & 0.050 \\
\hline Spain & & & & & 0.305 & $0.791^{*}$ & 0.450 & 0.023 \\
\hline UK & & & & & 0.472 & $1.309^{* * *}$ & 0.326 & 0.111 \\
\hline Scandinavia & & & & & 0.105 & 0.266 & 0.350 & 0.059 \\
\hline $\begin{array}{l}\text { Other European } \\
\text { Countries }\end{array}$ & & & & & 0.017 & 0.043 & 0.353 & 0.054 \\
\hline US and Canada & & & & & 0.295 & $0.763^{* *}$ & 0.392 & 0.033 \\
\hline South America & & & & & -0.120 & -0.327 & 0.588 & 0.010 \\
\hline Africa & & & & & -0.116 & -0.316 & 0.604 & 0.015 \\
\hline Japan & & & & & 0.120 & 0.304 & 0.375 & 0.036 \\
\hline Constant & & $-2.387^{* * *}$ & 0.555 & 1.000 & & $-2.249^{* * *}$ & 0.479 & 1.000 \\
\hline
\end{tabular}

Mean dependent variables are 0.517 and 0.454 for Cases and Firms, respectively

Pseudo $\mathrm{R}^{2} \mathrm{~s}$ are 0.268 and 0.537 for cases and firms, respectively

$*, * *, * * *$ Significance at the 10,5 , and $1 \%$ significance levels, respectively 
the administration in office. An important and significant determinant for the decision whether or not to appeal an infringement decision is the level of the fine. The higher is the fine, the higher is the probability that one or more parties will appeal. Parties hope to receive a reduction of their fine on appeal. The two cases with highest fines in which there was no appeal were Fine Art Auction Houses ( $€ 20.4$ million) and Food Flavor Enhancers ( $€ 20.6$ million), both concluded in 2002. The marginal effect indicates that the probability of an appeal increases by two percent points with a doubling of the fine. The number of parties to which the decision is addressed has a significant positive effect on the probability that there is an appeal of the case. This is not surprising since each party may consider appealing. The marginal effect suggests that each additional party increases the appeal probability by one percentage point.

The length of the decision in terms of the number of recitals also is a significant determinant of the probability that an appeal is lodged. We have previously interpreted the length as an indicator of the perceived complexity of the case. This suggests that such cases have more issues to challenge. The marginal effect indicates that a doubling of the number of recitals corresponds to a twelve percentage points higher appeal probability. The effect disappears for the firm-level regressions. Firms are more likely to appeal Article 82 cases and when other firms are also appealing. Firms in developing countries (South America and Africa) are less likely to appeal than are North American companies and companies in the large European countries, especially the United Kingdom.

\section{Concluding Remarks}

We provide a statistical analysis of all formal decisions under the Articles 81, 82, and 86 of the EC Treaty from the first decision in 1964 up to and including the last decision in 2004. Regulation 1/2003 meant the end of the notification system, and it therefore provides a natural last year for our sample period. Over time, the European Commission has developed its perception and enforcement of the competition rules in several dimensions. This paper provides the background for this development over more than four decades.

There are several limitations. One lies in the fact that only very general case characteristics have been analysed. Another limitation is that only violations that were uncovered and for which sufficient evidence was found are published. Many antitrust violations may have gone unnoticed. The current focus of the Commission on the key infringements of cartels and cases of abuses of dominance might, for example, have led to less attention to cases of vertical restraints.

Our paper has presented evidence of differences across sectors and across countries. These differences are in terms of share of infringements, of economic conduct, of fining, and of appeal probability. It has found that firms from non-European countries have fewer infringements, lower fines, and also lower appeal rates. This suggests that antitrust policy is not used as an instrument to frustrate non-European competitors. The probability of appeal was found to be strongly influenced by the fine imposed, by nationality of the firm, by economic conduct, and by whether other firms also appealed in the same case. This may raise interesting questions with respect to the success of appeal, which we leave for future research. 
There have been many changes to enforcement over time: in the areas of block exemptions, case law, regulations, number of Member States, anti-cartel units, leniency, merger control law, Member State authorities (NCAs), and so on. European competition law enforcement has matured: Decisions concentrate on infringements, are much more detailed, and are made much faster, and fines are much higher.

This does not mean that there are no critical observations. For example, the success of the leniency program has been under some dispute. It has been argued that the 1996 leniency notice has largely uncovered failed, not active cartels and that most cases were initiated previously in the U.S. ${ }^{77}$ The high fines in the cartel cases and the Microsoft case have made the Commission's antitrust work more visible than ever. The enhanced importance of the Commission's work makes mistakes increasingly costly. The strongly increased appeals rate following the 1998 fining guidelines indicates that firms are much more inclined to argue for lower fines. The extent to which they are successful may suggest regulatory failure with high legal costs. However, the increased rate may also be a temporary phenomenon where parties have to get used to tougher enforcement and higher fines.

Open Access This article is distributed under the terms of the Creative Commons Attribution Noncommercial License which permits any noncommercial use, distribution, and reproduction in any medium, provided the original author(s) and source are credited.

\section{Appendix: Description of the Data of Commission Decisions}

The cases are retrieved from the formal decisions of the Commission published over the years in the Reports of Commission Decisions Relating to Competition (hardcopy version from 1964 until 1998) as well as the Annual Reports on Competition Policy (from 1971 onward) and the Commission website. Initially, we used the Commission's collection in: European Commission, Reports of the Commission Decisions relating to competition, for the years: 1964-1973, 1973-1980, 1981-1985, 1986-1988, 19891990, 1990-1992, 1993-1994, 1994-1998, Office for Official Publications of the European Communities, Luxembourg.

Thereafter the cases were retrieved from the Commission website, as the official source. The Annual Reports were consulted for a confirmation of the information. In these reports, the Commission arranges the cases according to the five types of alleged economic conduct that are also employed in this paper. To guarantee completeness of the data, the set was checked against the publications in the Official Journal. We corrected minor deviations between the information in the Official Journal and on the Commission's web pages. All relevant public information published in the documents has been included. Some information was censored by the Commission for reasons of confidentiality. The data were checked by independent proofreaders.

77 See, e.g., Stephan (2005). 


\section{References}

Baker, J. B. (2003). The case for antitrust enforcement. Journal of Economic Perspectives, 17(4), 27-50. Bergman, M. A., Jakobsson, M., \& Razo, C. (2005). An econometric analysis of the European Commission's Merger decisions. International Journal of Industrial Organization, 23, 717-737.

Bos, I., \& Schinkel, M. P. (2006). On the scope for the European Commission's 2006 fining guidelines under the legal maximum fine. Journal of Competition Law and Economics, 2(4), 673-682.

Connor, J. M. (2006). Effectiveness of antitrust sanctions on modern international cartels. Journal of Industry, Competition and Trade, 6, 195-223.

Corwin, E. D. (1992). Trends in enforcement of the antimonopoly laws, in antitrust and regulation (pp. 110-118). London: Elgar.

Davies, S., \& Lyons, B. R. (2007). Mergers and merger remedies in the EU: Assessing the consequences for competition. Cheltenham: Edward Elgar.

Davies, S. W., Nigel, L. D., \& Clarke, R. (1999). Monopoly in the UK: What determines whether the MMC finds against the investigated firms? Journal of Industrial Economics, 47, 263-283.

Duso, T., Gugler, K. P. \& Yurtoglu, B. (2006). How effective is European merger control? WZB, Markets and Politics Working Paper No. SP II 2006-12.

Duso, T., Neven, D. J., \& Röller, L. H. (2007). The political economy of European merger control: Evidence using stock market data. Journal of Law \& Economics, 50, 455-489.

Faull, J. \& Nikpay, A. (Eds.). (2007). The EC law of competition. Oxford: Oxford University Press.

Friederiszick, H. W., Röller, L.-H., \& Verouden, V. (2006). European State Aid Control: An Economic Framework. In P. Buccirossi (Eds.), Advances in the economics of competition law. Cambridge, MA: MIT Press.

Gallo, J. C., Craycraft, J. L., \& Bush, S. C. (1985). Guess who came to dinner: A statistical study of federal antitrust enforcement for the period 1963-1984. Review of Industrial Organization, 2, 106-130.

Gallo, J. C., Craycraft, J. L., \& Dutta, S. (1986). Incarceration and fines: An empirical study of antitrust sanctions. Review of Industrial Organization, 3, 38-66.

Gallo, J. C., Dau-Schmidt, K. G., Craycraft, J. L., \& Parker, C. J. (1994). Criminal penalties under The Sherman Act: A study of law and economics. Research in Law and Economics, 16, 1-73.

Gallo, J. C., Dau-Schmidt, K., Craycraft, J. L., \& Parker, C. J. (2000). Department of Justice antitrust enforcement, 1955-1997: An empirical study. Review of Industrial Organization, 17, 75-133.

Geradin, D., \& Henry, D. (2005). The EC fining policy for violations of competition law: An empirical review of the commission decisional practice and the community courts judgments. European Competition Journal, 1(2), 401-473.

Ghosal, V., \& Gallo, J. (2001). The cyclical behavior of the Department of Justice Antitrust Enforcement Activity. International Journal of Industrial Organization, 19, 27-54.

Ghosal, V., \& Stennek, J. (2007). The political economy of antitrust. Amsterdam: North-Holland.

Gual, J., \& Mas, N. (2005). Industry characteristics and anti-competitive behaviour: Evidence from the EU. IESE Business School working paper.

Harding, C., \& Gibbs, A. (2005). Why go to court in Europe? An analysis of cartel appeals, 1995-2004. European Law Review, 30, 349-362.

Jones, C., \& van der Woude, M. (2006). EC competition law handbook (17th ed.). London: Thomson Sweet \& Maxwell.

Jorde, T. M., \& Teece, D. J. (1990). Innovation and cooperation: Implications for competition and antitrust. Journal of Economic Perspectives, 4(3), 75-96.

Korah, V. (2001). The interface between intellectual property and antitrust: The European experience. Antitrust Law Journal, 69, 801-839.

Kovacic, W. E., \& Shapiro, C. (2000). Competition policy: A century of economic and legal thinking. Journal of Economic Perspectives, 14(1), 43-60.

Lauk, M. (2002). Econometric analysis of the decisions of the German Cartel Office, working paper. Technische Universität Darmstadt and in German in 2003 in Jahrbücher für Nationalökonomie und Statistik, 223, 680-711.

Lin, P., Baldev, R., Sandfort, M., \& Slottje, D. (2000). The US antitrust system and recent trends in antitrust enforcement. Journal of Economic Surveys, 14, 255-306.

Lyons, B. R. (2004). Reform of European merger policy. Review of International Economics, 12, $246-261$.

Neven, D. J. (2006). Competition economics and antitrust in Europe. Economic Policy, 21, 741-791.

Nillsen, T. (1997). On the consistency of merger policy. Journal of Industrial Economics, 45, 89-100. 
Perloff, J. M., Rubinfeld, D. L., \& Ruud, P. (1996). Antitrust settlements and trial outcomes. Review of Economics and Statistics, 78, 401-409.

Posner, R. A. (1970). A statistical study of antitrust enforcement. Journal of Law and Economics, 13, $365-419$.

Posner, R. A. (2001). Antitrust law (2nd ed.). Chicago: The University of Chicago Press.

Priest, G. L., \& Klein, B. (1984). The selection of disputes for litigation. Journal of Legal Studies, 13, 1-55.

Ritter, L., \& Braun, W. D. (2005). European competition law. A practitioner's guide (3rd edn). London: Kluwer Law International.

Roeller, L. H., \& Stehmann, O. (2006). The year 2005 at DG competition: The trend towards a more effects-based approach. Review of Industrial Organization, 29, 281-304.

Russo, F., Schinkel, M. P., Günster, A. \& Carree, M. (2010). European commission decisions on competition. Cambridge University Press (forthcoming).

Salop, S. C., \& White, L. J. (1986). Economic analysis of private antitrust litigation. Georgetown Law Journal, 74, 1001-1064.

Schinkel, M. P. (2007). Effective cartel enforcement in Europe. World Competition, 30, 539-572.

Shaw, R. W., \& Simpson, P. (1986). The persistence of monopoly: An investigation of the Effectiveness of the United Kingdom Monopolies Commission. Journal of Industrial Economics, 34, 355-372.

Stephan, A. (2005). An empirical analysis of the 1996 leniency notice, CCP Working Paper 05-10. University of East Anglia, Norwich.

Veljanovski, C. (2007). Cartel fines in Europe: Law, practice and deterrence. World Competition, 30, $65-86$.

Vogelaar, F. O. W. (2007). The European competition rules; Landmark cases of the European Courts and the Commission (2nd edn.). Groningen: Europa Law Publishing.

Wils, W. P. J. (2002). The optimal enforcement of EC antitrust law. The Hague: Kluwer Law International.

Wils, W. P. J. (2005). Principles of European antitrust enforcement. Oxford: Hart Publishing. 